\title{
LA AGENCIA EN MADRID DEL VIII DUQUE DE MEDINA SIDONIA, 1615-1636
}

\author{
Luis SAlas Almela \\ Instituto Universitario Europeo de Florencia
}

RESUMEN: En este artículo se aborda una institución hasta el momento totalmente ignorada por la historiografía: las agencias de representación nobiliarias. A partir del caso de estudio de los duques de Medina Sidonia, y más en concreto del VIII duque, don Manuel Alonso Pérez de Guzmán, se analizan las formas de ejercicio de un poder que, si bien alejado físicamente de la Corte real, lograba hacerse presente en el círculo de poder regio. Los cambios de coyuntura que tuvieron lugar en los años del VIII duque hacen su caso particularmente útil como ejemplo de una política secular del linaje de los Pérez de Guzmán. Así, se busca superar la cierta marginación a que los estudios sobre la Corte regia han sometido a esos otros poderes que no podemos seguir considerando simplemente como «periféricos».

Palabras Clave: Nobleza. Poder. Clientelas. Representación. Andalucía. Corte. Felipe IV. Olivares.

ABSTRACT: This article faces one institution, never studied before as such: the agencies of representation beld by noble bouses in the Royal Court. The case study of the House of Medina Sidonia in the years of the VIII duke provides an excellent starting point in order to study how noble power managed to make their voice be heard among the king's closest circle of decision. The changes that took place during this period allow us to present it as a significant example of the long-term political strategy of the Medina Sidonia House. By this, we seek to avoid the relative exclusion of the socalled "periphery» by a certain historiography of the power phenomena in the Early Modern History, excessively concentrated inside the boundaries of the Royal Palace.

KeY WORDS: Nobility. Power. Clienteles. Representation. Andalusia. Court. Philip IV. Olivares. 
«[...] que el sol alumbra de lejos, y para obrar en la tierra no se arranca de su orbe» 1 .

Cuando Pedro Espinosa empleó para referirse a su señor, el VIII duque de Medina Sidonia, don Manuel Alonso Pérez de Guzmán el Bueno, la metáfora del Sol estaba recreando el significado que el astro rey tenía en el lenguaje político y simbólico de la época como alusión a uno de los atributos de la majestad: la gracia. El brillo de la merced del rey venía siendo presentado por la literatura política como una luz capaz de iluminar con su benefactora influencia todos los confines de la Monarquía. Sin embargo, este sol del duque de Medina Sidonia al cual se refería Espinosa salvaba una distancia inversa, desde el palacio ducal de Sanlúcar, para hacerse notar precisamente en la Corte del rey Católico.

Las agencias de representación nobiliaria, que hasta ahora no han sido estudiadas, deben ser entendidas como puente o nexo entre dos espacios físicos y políticos diferentes - aunque dependiente el uno del otro-, entre dos cortes cuyo grado de afinidad estaba sometido a mudanzas ${ }^{2}$. El poder regio canalizaba este contacto a través de una multiplicidad de tribunales y órganos de gobierno, tanto en el nivel local — corregimientos, audiencias y chancillerías-, como en el espacio más inmediato al rey — su Corte, compuesta de Consejos, Juntas, secretarios y validos. Cuando el volumen de negocios sostenidos en los niveles cortesanos era muy elevado, aquellos grandes señores que por una u otra causa no residían cerca del monarca hubieron de recurrir a la contratación de uno o varios individuos que llevasen su representación. Las agencias responden así a una necesidad de negociación y comunicación de las grandes Casas señoriales, en cuanto que estructuras de dominio social, con el poder superior de la Corona.

Por su parte, la Casa de Medina Sidonia viene siendo incluida en la bibliografía al uso como conspicuo ejemplo de un modelo andaluz de nobleza, modelo aún pendiente de una definición precisa en cuanto a las especificidades de su poder en comparación con otros casos, pero que, al menos, tiene la utilidad de señalar algunas características generales válidas de aquellas grandes Casas, como son su ausencia más o menos permanente de la Corte real y la fuerte concentración geográfica de sus señoríos. Ambas características justifican la necesidad de la

\footnotetext{
${ }^{1}$ EsPinOSA, Pedro: «Elogio al duque de Medina Sidonia», [Málaga, 1625] en LóPEZ Estrada, Francisco: Pedro Espinosa. Obra en prosa, Málaga, 1991, p. 298.

${ }^{2}$ En cambio sí que han sido estudiados los agentes de representación territorial o urbana. Así, para el caso del reino de Murcia ver García Hourcade, J.J. y Ruíz IbáÑEZ, J.J.: «Un poder simbiótico: la articulación de los lazos de dependecia entre la Corona y los mediadores, Murcia ss. XVI-XVII», en GUILLAmón, F.J. y RUIZ IBÁÑEZ, J.J.: Lo conflictivo y lo consensual en Castilla. Sociedad y poder político (1521-1715), Murcia, 2001; y RUíz IBÁÑEZ, J.J. y MUÑOZ RODRíGUEZ, J.D.: «Sirviendo a la Corte en la aldea, sirviendo a la aldea en la Corte: veteranos, agentes y medios de relación en el siglo XVII castellano", en Bravo LOZANO, J.: Espacios de poder. Cortes, ciudades y villas (siglos XVI-XVIII), Madrid, 2002.
} 
Monarquía de contar con el concurso de estos poderosos señores para el mantenimiento de su autoridad en Andalucía ${ }^{3}$. En todo caso, y aunque la mayor parte de la gran nobleza castellana no fijó su residencia en la Corte hasta fines del siglo XVII, podemos considerar como una característica muy marcada de los duques de Medina Sidonia hasta la ruptura de 1641 su alejamiento físico, consciente y estratégico, de la Corte. Sin embargo, esa distancia física no era necesariamente política. Baste mencionar por ahora que cuando don Manuel Alonso Pérez de Guzmán el Bueno — de cuyo tiempo se ocupa este trabajo- heredó la corona ducal de Medina Sidonia era yerno del duque de Lerma, aún poderoso valido. En su tiempo asistió a la caída de su suegro, al ascenso imperfecto de su cuñado y al encumbramiento de su primo don Gaspar de Guzmán, ya en el reinado de Felipe IV, fases en las que el grado de colaboración entre ambas cortes varió en función de las coyunturas, como veremos. Precisamente esta evolución es la que justifica que hayamos utilizado la biografía política del VIII duque como hilo conductor de este trabajo. Entre su ascenso al trono ducal y su fallecimiento se produjeron altibajos y cambios de circunstancia de cuyo estudio podremos obtener una idea cabal de los modos de relación del poder nobiliario con el regio.

Los duques de Medina Sidonia mantuvieron de forma estable a lo largo de la Edad Moderna — con una cronología variable - tres agencias en el interior de la Corona de Castilla. La primera, con sede en Granada, presenta un carácter eminentemente jurídico, siendo su actividad la defensa legal de los derechos de la Casa en los incesantes pleitos que se entablaban con los vasallos o con los ministros reales que, de una u otra forma, chocasen en su acción con la autoridad del duque. Una segunda agencia tenía por sede Sevilla, siendo la que mayor actividad presenta. En este caso, las cuestiones tratadas son muy variadas, no siendo infrecuentes en determinadas épocas pleitos seguidos ante la Audiencia hispalense derivados de las posesiones de los duques en la ciudad y su alfoz. Su actividad incluía también una representación política — simbolizada por la ocupación que hacía el agente del majestuoso palacio de los duques en el corazón de la ciudad - derivada de la actividad fiscal y militar del duque en Sanlúcar, la cual repercutía de forma inmediata en Sevilla, así como a la inversa toda la actividad comercial de Sevilla influía en la capital ducal. La nota distintiva de esta agencia, sin embargo, era su carácter financiero, derivado sin duda de que Sevilla fuese uno de los principales mercados y plaza de cambios de toda Castilla. A partir de esta agencia Medina Sidonia situaba importantes partidas de dinero dónde y cuándo lo precisaba, muy especialmente en Madrid, lugar de actividad de la tercera agencia, de la cual nos vamos a ocupar. Aún debemos señalar la existencia de una cuarta agencia localizada fuera de los límites de la Corona de Castilla, en concreto en Roma ${ }^{4}$.

\footnotetext{
3 García Hernán, David: La nobleza en la España Moderna, Madrid, 1992; CARrasco MARTÍNEZ, Adolfo: Sangre, bonor y privilegio. La nobleza española bajo los Austrias, Madrid, 2000.

${ }^{4}$ De esta agencia, cuya principal actividad cabe suponer que fuera la gestión del patronato eclesiástico de los Medina Sidonia ante la Corte papal, no se ha conservado una serie documental
} 
La fuente específica utilizada para la elaboración de este trabajo es la serie de legajos que responden al título de "Cuentas de la Agencia de Madrid», conservada en el Archivo Ducal de Medina Sidonia (ADMS), ubicado en Sanlúcar de Barrameda, en la actual provincia de Cádiz. En esta colección documental abundan las cuentas de gastos y sus correspondientes recibos. Pero además incluyen toda una colección epistolar entre los agentes y el duque, plena de valoraciones e instrucciones, serie que, si bien incompleta, nos ha permitido rastrear los avatares de este organismo y sus características funcionales e institucionales. Me he limitado aquí a abordar los aspectos que vinculaban al duque con la Corte en los cuales nos consta un activo papel de la agencia madrileña, que es al cabo el objeto de estudio de estas páginas. Sin embargo, más allá del valor excepcional de esta fuente, el hecho de que nunca antes se haya estudiado una agencia nobiliaria se ha debido más bien a ciertos planteamientos metodológicos. En concreto, el hecho de que casi cualquier relación de poder haya quedado encuadrada en el concepto de «red clientelar» y que se haya entendido que toda red conduce en última instancia al rey, ha sido, en nuestra opinión, el factor clave de este desinterés. No es ajeno tampoco el hecho de que el estudio de las clientelas se haya desarrollado de forma paralela al resurgir historiográfico del interés por la Corte regia como centro de poder ${ }^{5}$. Según este esquema, un centro, dominado por el monarca, se impondría por medio de su Corte —en un sentido amplio- a una periferia en la que se ubicaban aquellos poderes que no podían acceder a los círculos más próximos al rey ${ }^{6}$. La atractiva idea de entender la Corte como «punto de contacto entre gobernantes y gobernados» ha producido un consecuente olvido de las realidades políticas que no se ajustaban a este esquema. Sin negar los logros de estas corrientes, en las conclusiones de este trabajo expondremos algunos puntos para el debate.

\section{ESTRUCTURA Y FINANCIACIÓN}

La agencia cortesana de los duques de Medina Sidonia fue evolucionando como estructura institucional desde el asentamiento de la Corte de Felipe II en Madrid hasta su grado definitivo de desarrollo, alcanzado hacia 1590. La agencia, como tal institución, surge desde el momento en el que se delegan en una persona concreta ciertas funciones de representación del señor. Por tanto, sólo tiene sentido hablar de agencia cuando un ministro del duque asume la responsabilidad de coordinar todas las funciones de los demás asalariados y deudos

\footnotetext{
específica, como en el caso de las anteriores, por lo que las referencias de las que disponemos son bastante imprecisas.

5 El gran antecedente de estos estudios es el conocido libro de Norbert ELIAS: La sociedad cortesana, Madrid, 1982 [1975].

${ }^{6}$ La cita es de Martínez Millán, José: «Introducción», en Martínez Millán, José (dir.): La corte de Felipe II, Madrid, 1994, p. 14.
} 
que asisten en la Corte. Antes de ese momento lo que encontramos son abogados o comisionados temporales que defendían los intereses de su señor en un pleito o situación concreta. La aparición del agente, cuya dedicación es exclusiva e incompatible con otras actividades profesionales, confiere una estructura jerárquica que dota a la representación misma del duque en la Corte real de un carácter más político.

A la hora de hacer un nombramiento para esta ocupación, que por muy diversas causas era muy apetecida, la opinión del consejo ducal -órgano asesor del duque en materias de justicia y gobierno- era al parecer vital. Una de las causas que hacía tan apetecible el cargo de agente en la Corte, amén de la retribución ${ }^{7}$, era la posibilidad que abría a quienes lo ocupaban de trabar una red personal de contactos tanto en la Corte como entre los ministros ducales, mediando en los negocios particulares de éstos últimos. Pero por encima de todo, el cargo de agente era valorado por ser una ocupación de confianza del duque, por lo que no es infrecuente que fuese un miembro del consejo ducal quien ejerciese de agente en Madrid $^{8}$. Un reflejo de la alta consideración de esta ocupación lo encontramos en una de las primeras cartas que el agente de Medina Sidonia en Granada remitió al recién nombrado agente en Madrid, don Gaspar de Liébana, el cual había sido hasta entonces su compañero de tareas en la Chancillería granadina. En aquella misiva mostraba una alegría no exenta de ambigüedad maliciosa al celebrar la buena acogida del agente en Madrid «mayormente sabiendo cómo vuestra merced goza de buena salud y de comodidad de casa y muchos amigos, con que se pasa alegremente. Sea por largos años»?.

La agencia contaba con un número variable de abogados y procuradores, generalmente cinco o seis, algunos de los cuales trabajaban a tiempo completo para el duque y otros no, aunque todos ellos tuviesen asignado un salario en los libros de acostamiento de la Casa. En general, cada uno de estos abogados llevaba entre manos un pleito, mientras que algunos letrados de prestigio cumplían la función de asesorar en las estrategias que había que seguir en los casos más graves. Aún nos encontramos con otros abogados cuyo servicio era realmente ocasional, siendo sus emolumentos destinados a un fin preciso - por ejemplo, se podía encargar un memorial en un pleito concreto, pagándolo a elevados precios ${ }^{10}$. Cualquiera de estas ocupaciones de abogados de la Casa era también apetecida, como prueba que en ocasiones fuesen letrados de la Corte los que se acercasen a la agencia para ofrecer sus servicios. Así, en 1628, el duque respondió a la oferta que un abogado presentó al agente Liébana diciendo

7 El sueldo de agente en 1616 — siéndolo Alonso de Vergara - alcanzaba los 200 ducados. ADMS, leg. 2.949, cargo y data del año 1616.

8 Tal es el caso del consejero ducal Nuño González Nacelo, nombrado agente a la muerte de su antecesor, Pedro de Vallejo Cabañas. ADMS, leg. 3.001.

9 ADMS, leg. 3.063, carta de 7 de noviembre de 1628.

${ }_{10}$ Así se pagó por este servicio a un abogado la suma de 500 reales según las cuentas de Jerónimo Altamirano de 1617. ADMS, leg. 2.949, cargo y data de 1617. 
que «tenemos tantos abogados en esa Corte que podría ser embarazo nombrar otro de nuevo». Por eso ordenaba al agente que respondiese al solicitante que en la primera vacante que se produjese se contaría con él, dilatando una respuesta más firme sin que «haga falta hacer demostración» ${ }^{11}$.

Por otra parte, en ocasiones, junto a los agentes titulares, encontramos comisionados temporales — casi siempre también con nombre de agentes - para tratar un determinado asunto o para cubrir un lapso temporal entre dos representantes estables. En todo caso, la instalación de un nuevo agente, ordinario o extraordinario, solía venir acompañada de alguna libranza más allá del sueldo ordinario en concepto de ayuda de costa para la instalación en la Corte ${ }^{12}$. Desde luego, esta generosidad debe ser contemplada en alguna medida como una forma de gasto suntuario, toda vez que la instalación en la Corte de quien iba a ser la representación de un gran señor no debía hacerse, ni aún siendo temporal su comisión, con estrecheces, sino con la mayor decencia posible ${ }^{13}$.

Para calibrar con cierta precisión la importancia que tenía para la agencia de la Corte el abastecimiento de dinero, debemos reparar en el lugar en que desenvolvía su actividad, ese entorno del rey Católico que era el escenario de la ostentación aristocrática por excelencia. Esto exigía que quien representaba a la Casa más opulenta de Castilla pudiese dar muestra constante de su capacidad de gasto. Además, los asuntos tratados en los Consejos nunca debían sufrir retrasos, porque una dilación de días en la elaboración de un memorial, en la votación de una causa o en la compra de un favor en la Corte podía suponer un costo altísimo para la Casa. Por ambas razones, era vital mantener la agencia con liquidez y crédito, por lo que se buscaron las formas más seguras y variadas de hacer llegar el dinero a la Corte.

En el aspecto financiero, la inserción de la agencia de Madrid en el organigrama de la Casa ducal la sitúa en dependencia directa de la más alta institución de gestión de las finanzas del duque de Medina Sidonia, la contaduría mayor de Sanlúcar, lo que equivale a decir que se constituía en tesorería independiente. La figura del tesorero —al parecer permanente en el organigrama de la agencia - quedaba encargado de recibir el dinero y habitualmente participaba, de mancomún con el agente, en la validación de todos los recibos y libranzas, con la excepción de los gastos secretos. En todo caso, la figura del tesorero quedaba subordinada al agente en materia de gasto, siendo su razón de ser el mantenimiento de una vía fluida de entrada del dinero. De todos modos, no conocemos instrucciones sobre los protocolos ordinarios de uso del di-

11 ADMS, leg. 3.063, noviembre de 1628.

12 A Liébana le fueron entregados a su llegada a Madrid 500 ducados, 200 extraordinarios y otros 300 para gastos ordinarios. ADMS, leg. 3.063, cargo y data de 18 de agosto de 1628 .

13 Así, a fray Alonso Nuño, cuyo cargo de agente era provisional, le fue señalado en 1628 un salario de 24 reales al día «para el gasto de su persona y regalo de vuestra merced», el cual iría cobrando desde el 24 de diciembre de 1627, día que salió de Sevilla. Además el duque pagaba su transporte en litera —a razón de 32 reales al día. ADMS, leg. 3.001, cargo y data de 1627. 
nero de la agencia. Lo más parecido que tenemos son unas instrucciones que el duque redactó para el licenciado fray Nuño González Nacelo - agente provisional - en las que era informado de cómo debía distribuir el dinero que entrase en su poder. En primer lugar, se le indicaba lo que a él mismo le correspondía. Por otra parte, llevaba carta para que don Pedro Dávila — tesorero de la agencia- le entregase 500 ducados que Nacelo distribuiría entre los abogados - por ejemplo, dos partidas de 500 reales a Pedro de Robles para «gastos menudos» de los pleitos. En instrucción aparte, se le indicaba cómo pagar a los demás abogados, procuradores y solicitadores a los que, al parecer, se les debían atrasos de su sueldo. Así mismo, se le informaba de que debía seguir haciendo los pagos a dos hermanos del duque residentes en Madrid, el Patriarca de las Indias - a quien socorría Medina Sidonia en sus gastos con 4.000 ducados anuales- y el marqués de Fuentes — con 2.000 ducados $^{14}$. A ambos debía avisar Nacelo que por no tener el duque agente estable en la Corte —el anterior había fallecido y aún no se había elegido sustituto- no era fácil hacerles llegar el dinero, de modo que para que «se pague a sus señorías con puntualidad, [...] vean en Sevilla o Sanlúcar a quien quieren [que] se entregue» ${ }^{15}$.

Dada la superioridad jerárquica del agente también en materia de gasto, era él quien casi siempre rendía cuentas al contador mayor del duque en Sanlúcar. Así, con una periodicidad aproximadamente anual, el agente debía remitir sus cuentas, tras recibir orden en tal sentido del contador mayor, para ser revisadas en el palacio ducal ${ }^{16}$. En lo que respecta a la evaluación del gasto, que en sus aspectos cualitativos se verá reflejado en los apartados siguientes, puede servir de orientación el cuadro que presentamos a continuación. Si bien la diversidad de formas contables entre unos años y otros nos impide un tratamiento estadístico de la información, podemos sugerir algunas líneas de evolución en las diversas partidas que presentamos. Destacan en primer lugar las diferencias en el nivel de gastos en pleitos, que se justifican por la aparición de nuevas demandas - en 1634 la parte del león se la llevaba el pleito de la sal, como veremos. En este sentido, el hecho de que el año de menor gasto en pleitos corresponda con el de mayores salarios tiene sin duda que ver con la forma de retribución de los

${ }_{14}$ Se trata de don Alonso Pérez de Guzmán —nacido (en adelante, n.) 1590 — fallecido (m.) 1670-, cuarto hijo varón del VII duque de Medina Sidonia, Patriarca de las indias por merced de Felipe IV y de don Juan Claros de Guzmán (n. 1597 - m. hacia 1637), IV conde de Saltes y marqués de Fuentes por matrimonio con doña Francisca de Fuentes.

15 ADMS, leg. 3.001, diciembre de 1627. Ambos siguieron recibiendo dinero de su hermano por medio de su agente en los años siguientes. Así, cuando en 1629 se acabaron de tramitar los títulos del marqués, el agente recibió orden de pagar los gastos de gestión y sello como un regalo del duque a su hermano (550 ducados); por lo que respecta a la ayuda al Patriarca, parece que se redujo al principio de los años 1630 a tres pagas anuales de 11.000 reales. ADMS, leg. 3.063, 12 de diciembre de 1627, 20 de julio de 1629 y 30 de abril de 1631 .

${ }_{16}$ Tal fue la excusa que presentó el agente don Jerónimo de Escobedo en 1619 al contador mayor del duque por su retraso. ADMS, leg. 2.949, carta de 2 de abril de 1619. 
letrados y la inclusión de sus partidas en una u otra categoría, dependiendo de si estaban activos en una causa o sólo mantenidos como asesores. En cuanto a las partidas de compras y representación, por su propia naturaleza muy variables, parece que fueron absorbidas por el conde de Niebla en el tiempo que estuvo en Madrid. En cuanto a los dos últimos conceptos, deben ser tomados con mucha precaución, ya que los gastos tendentes a granjearse el favor de ministros o prominentes cortesanos se incluían entre los «gastos secretos». Sin embargo, es de reseñar que en los años de 1630 algunas figuras destacadas, como el cronista regio Gonzalo de Céspedes y Meneses, figuren precisamente en la contabilidad ordinaria como receptores de mercedes ducales.

GASTO DE LA AGENCIA DE MADRID, 1617, 1626 Y $1634^{17}$

(datos en reales)

\begin{tabular}{|l|c|c|c|}
\hline CONCEPTO & 1617 & 1626 & 1634 \\
\hline Pleitos & 9.443 & 6.515 & 12.788 \\
\hline Salarios & 11.722 & 24.384 & 17.221 \\
\hline Compras & 16.818 & 846 & \\
\hline Representación & 887 & 3.465 & \\
\hline Conde de Niebla & & & 21.780 \\
\hline Mercedes & 52.141 & 2.809 & 5.574 \\
\hline Sin especificar & 5.876 & 100 & 1.072 \\
\hline Totales $(*)$ & $105.640(* *)$ & 53.165 & 58.025 \\
\hline
\end{tabular}

(*) Los totales que se reflejan aquí son los que figuran en las cuentas. Las diferencias con la suma de los datos incluidos en este cuadro se deben sobre todo a que aquí no se han incluido las partidas remanentes de otras cuentas, pero también a los cambios de moneda y a algunas cifras ilegibles.

(**) Este año se incluyó la compra de una casa en Madrid para Tello de Guzmán, hermano del duque, por valor de 50.000 reales.

Nota: Los datos no corresponden a años naturales, sino que los periodos comprendidos en cada cuenta son variables, oscilando entre los nueve meses de la columna de 1626 a los 15 de 1634. Los conceptos incluyen diversas partidas. Pleitos: abogados ocasionales, correos, salarios de jueces y tramitaciones ordinarias y extraordinarias ante los tribunales regios. Mercedes: regalos del duque a personajes de la Corte, a familiares y a criados propios de la Casa ducal. Compras: objetos de lujo para el duque. Conde de Niebla: partida establecida para su sostenimiento, no siempre pagada por la vía ordinaria. Representación: gasto en visitas ceremoniales (pésames, felicitaciones o recibimientos fuera de Madrid). Sin especificar: suelen figuran como gastos por orden expresa del duque. Salarios: del personal de la agencia asentado en los libros de cuentas.

Fuente: Elaboración propia a partir de los datos procedentes de AMDS, legs. 2.949, 3.001 y 3.084.

${ }^{17}$ Los años han sido escogidos sobre todo por ofrecer una documentación fiable en lapsos de tiempo similares que abarcan todo el periodo de estudio. 
En cuanto a la procedencia del dinero, también era el contador mayor el encargado generalmente de remitir las partidas y aprobar los envíos que de cualquier otra tesorería del duque se hiciesen para el sostenimiento de la agencia en la Corte ${ }^{18}$. No es frecuente, por lo demás, que el agente tratase las cuentas con su señor, pero en el caso de don Pedro Vallejo, por la especial confianza que parece haber gozado de su señor, sí que encontramos alguna intervención directa del duque ${ }^{19}$.

El tesorero don Pedro Dávila — que lo fue entre 1628 y 1632 - es una figura muy interesante para introducirnos en las formas de allegar dinero a la agencia. Comerciante en la Corte y miembro de una familia con tradición secular de servicio a los duques de Medina Sidonia, sobre todo en puestos de hacienda, se da la circunstancia de que cuando fue promovido a tesorero de la agencia de Madrid su primo, don Lorenzo Dávila, era contador mayor del duque en Sanlúcar ${ }^{20}$. La elección no era casual, ya que la cercanía familiar del encargado de las finanzas de la agencia con quien a la postre las alimentaba podía sin duda facilitar el tráfico del dinero en un momento en el que la liquidez de su señor empezaba a resentirse. El propio contador mayor remitió una carta al agente del duque en Madrid — don Gaspar de Liébana - en la que, tras alegrarse por el hecho de que su primo estuviese en la Corte para ayudarle, le advertía de que «está esta hacienda del duque mi señor tan apurada, con las malas cobranzas y la general necesidad, que yo que la administro y a quien todos acuden [para] que les haga pagar, temo perder el crédito en negocios míos. Dios lo remedie ${ }^{21}$. Pese a aquellas advertencias, apenas unos meses después de su llegada a Madrid, Liébana hubo de escribir a don Lorenzo pidiéndole que le ayudase a cumplir con los atrasos de los sueldos de los demás ministros de la agencia, porque unos y otros «me pican por lo mismo y los demás abogados y procuradores comienzan a solicitar». Añadía que «aunque yo deseo hacerlo bien con ellos no puedo si vuestra merced no me ayuda. Yo no quisiera ser molesto ni cansar a vuestra merced sobre lo que de mi condición es más penoso el pedir» ${ }^{22}$. En todo caso, el concepto clave al que aludía era el crédito del contador, argumento que nos pone sobre la pista de aquello que podía allanar el vínculo familiar entre ambos ministros de la hacienda ducal: la circulación de dinero. Por lo

18 Resumen de esta triple función de supervisión financiera del contador mayor es una carta de Escobedo al señor licenciado don Jerónimo de Abreu y Soria, a la sazón ocupado en tal oficio, en la que le daba aviso de haber cumplido lo ordenado enviando las cuentas (de las que pedía aprobación), pidiéndole además más fondos con los que ir afrontando los gastos extraordinarios. En posdata, daba aviso de haber recibido los ducados que Abreu había ordenado remitir desde Sevilla. ADMS, leg. 2.949, 16 de enero de 1617.

19 ADMS, leg. 3.001, d. 497, cartas de 17 de marzo y 3 de abril de 1626.

20 Ver VelázQuez Gaztelu, Juan Pedro: Catálogo de todas las personas ilustres y notables de esta ciudad de Sanlúcar de Barrameda, Sanlúcar, 1996 [1760], pp. 157-162.

${ }_{21}^{21}$ ADMS, leg. 3.063, carta de 29 de octubre de 1628.

22 ADMS, leg. 3.063, carta de 7 de noviembre de 1628, 
demás, la mención a la propia fortuna en el ejercicio de los cargos de hacienda refuerza la impresión que trasmiten las cuentas anuales de que no era infrecuente que el agente alcanzase a la hacienda del duque. Esto significa que el agente había tenido que adelantar fondos o solicitarlos a terceros, usando su crédito personal como garantía para afrontar pagos a cuenta del duque ${ }^{23}$.

A través de las cuentas anuales podemos reconstruir la procedencia de los dineros del duque en Madrid, que podemos agrupar en cuatro fuentes diversas. En primer lugar, por orden de importancia, las partidas giradas por la contaduría mayor de Sanlúcar, generalmente en forma de letras, las cuales pasaban con bastante frecuencia por mano del tesorero de la agencia de Sevilla, ciudad en la que, como plaza de cambios, era más fácil a su vez reenviarlas a Madrid. Este sistema presentaba el inconveniente de los costes del movimiento de dinero, que en el periodo que nos ocupa no dejaron de crecer. En segundo lugar, destaca la presencia de los rendimientos de las almadrabas - las pesquerías de atún-, cuya aportación de fondos a la agencia madrileña se realizaba por medio de la venta del atún in situ en las chancas de Conil y Zahara a mercaderes madrileños que luego hacían efectivo el valor de lo comprado en la Corte. El sistema presentaba la nada despreciable ventaja de ahorrar los costos de gestión de las letras, además de suponer una forma de colocar en Madrid un producto de lujo claramente vinculado a la Casa de Medina Sidonia, reforzando en cierto modo la presencia simbólica del duque. Además, el propio atún se convertía muchas veces en regalo y agasajo de cortesanos y ministros por parte del duque - en su versión más exquisita, que eran los cuñetes de hijada ${ }^{24}$. Por último, de mucha menor importancia en el periodo que nos ocupa, nos encontramos ocasionales rentas percibidas por los duques en Sevilla o en la propia Corte ${ }^{25}$. De resultas de todo esto, la agencia de Sevilla era vital para su homóloga de Madrid, hasta el punto de que el buen entendimiento entre los responsables de ambas agencias podía llegar a ser crucial para el correcto funcionamiento de la segunda, dotando de contenido a las formulaciones de buenos deseos de servirse mutuamente que sistemáticamente expresaban unos y otros agentes ${ }^{26}$.

${ }^{23}$ En la cuenta de 1623 de don Juan de Castro, según explicaba en carta al contador mayor del duque, quedó alcanzada la hacienda del duque en 10.314 reales, dado que no se hacía cargo el agente de una letra de 20.000 reales que, pese a haber sido aceptada, seguía siendo tramitada. ADMS, leg. 3.001, d. 66, 14 de marzo de 1623.

${ }^{24}$ Sólo el transporte de una mercancía tan preciada - la parte más exquisita del atún, envasada en barriletes llamados cuñetes - de Sevilla a Madrid suponía un costo de 10 reales por arroba. Dos ejemplos entre tantos de recibos de este gasto en ADMS, leg. 3.001, d. 113 y 122, recibos de 1622.

${ }_{25}$ Así, de ciertas rentas que había disfrutado el VII duque en Canarias aunque cobradas en Madrid - al parecer sin facultad de supervivencia en su hijo- aún se le debían al heredar el VIII los corridos de los últimos meses. ADMS, leg. 2.949, cargo y data del año 1615.

${ }^{26}$ Por ejemplo, cuando Tomás Pérez entró a servir en la agencia sevillana, se comunicó de inmediato con don Juan de Castro, agente en Madrid, consciente de que una simple nota de aviso, además de poner en conocimiento del otro su nueva ocupación, era la forma de iniciar una relación epistolar inevitable. ADMS, leg. 2.949, carta de 12 de noviembre de 1619. 
Esta dependencia de la agencia de Madrid del mercado financiero hispalense se traducía en una aguda sensibilidad a las alteraciones del flujo comercial transoceánico. Así, los efectos de la pérdida de la flota del tesoro en Matanzas, que alteraron el mercado de la plata en Sevilla - donde el premio de la plata alcanzó el entonces nunca visto $21 \%$, como refería espantado el agente del duque en aquella ciudad a su homólogo en Madrid- ocasionó que ni siquiera los grandes asentistas, como los Spínola, estuviesen dispuestos a remitir letras a Madrid. La consecuente situación de apuro del agente en la Corte en 1629, a la sazón don Gaspar de Liébana, obligó a usar medios más o menos extraordinarios, como fue recurrir al concurso de un mercader portugués afincado en Sevilla - cristiano viejo y pariente de uno de los nuevos asentistas de Felipe IV-, Payo Ruiz de Paz, aprovechando la circunstancia de que acudía en persona a Madrid ${ }^{27}$. Por este medio se pudo hacer llegar un dinero vital, al que en el verano se sumaron otras partidas más por medio de los mercaderes del atún. No debemos dejar de señalar que en los años sucesivos Payo Ruiz realizó frecuentes transacciones de este tipo para el duque, pero que, más aún, su papel como garante de la liquidez de la agencia le llevó a entrevistarse de parte de Medina Sidonia con algunos de sus parientes en la Corte, como el Patriarca de las Indi$a^{28}$. En todo caso, a la mala situación general causada por la escasez de plata de aquel año se había unido el donativo que el duque había ofrecido al rey, lo que agudizó más la escasez de líquido del duque obligándole a pedir a su agente que moderase sus gastos ${ }^{29}$.

Sin embargo, sucedió lo contrario cuando en 1630 se multiplicaron los desembolsos con la llegada a Madrid de don Gaspar Pérez de Guzmán, conde de Niebla - hijo y heredero del duque-, que por sí mismo generaría un enorme gasto suntuario. El propio Payo Ruiz firmó un asiento con Medina Sidonia para enviar los alimentos a don Gaspar mientras estuviera en Madrid — que ascendían a la muy considerable cantidad de 12.000 ducados al año, equivalente a los ingresos brutos de muchas casas tituladas castellanas-, aunque al parecer hacia 1631 hubo problemas para hacer llegar el dinero. Aquellas deficiencias del sistema implicaron al contador mayor y a su primo, don Pedro Dávila — recordemos, tesorero de la agencia. Aquella era la ocasión de que el contador mayor recurriese a su familiaridad con don Pedro para representarle lo importante que era la aceptación de las letras de Payo Ruiz para el decoro del conde, sugiriéndole incluso que adelantase la cantidad de su propio bolsillo. Por otro lado, todos los implicados hicieron algo así como un pacto de silencio para que el retraso, que ya se había producido, no llegase a conocimiento del duque ${ }^{30}$. Sin embargo, las tensiones llegaron entonces al punto de provocar roces entre el contador mayor y el

27 Domínguez Ortiz, Antonio: Política y hacienda de Felipe IV, Madrid, 1960, pp. 123-125.

28 ADMS, leg. 3.063, cartas de 11 y 13 de febrero, 21 de julio y 16, 20 y 30 de octubre de 1629.

29 ADMS, leg. 3.063, carta de 22 de julio de 1629.

30 Cartas de don Lorenzo Dávila y Payo Ruiz a don Pedro Dávila. ADMS, leg. 3.083, 24 y 30 de septiembre de 1631 . 
agente Liébana. En una carta dirigida al agente, don Lorenzo Dávila protestaba de los reproches de que había sido objeto por parte de Liébana por no haberle podido hacer llegar una partida, "pues [aseguraba Dávila] yo no carezco de trazas, sino de dineros, que no lo alcanzamos ni sabemos qué hacernos». Es más, presumía el contador de que los 5.000 reales que había remitido a Madrid por vía de Francisco de Herrera se debían a su crédito, ya que, sin conocer personalmente a Herrera y sus consortes, le habían encomendado gran cantidad de plata fiando "de mí muchos ducados y crédito y yo de sus mercedes». Si hubiese tenido dinero, proseguía, no hubiera necesitado «rodeos [...] sino sacar la letra sobre los justinianos, que más conocidos son míos que de su merced los que aquí gobiernan esto» ${ }^{31}$.

Al margen de aquellos exabruptos, por entonces hizo su aparición, de la mano del mismo Dávila, un comerciante vasallo del duque que acabaría siendo, junto con su hermano, una pieza importante en los negocios de la Casa de Medina Sidonia: don Fernando de Novela. Su primera aparición en asuntos que trascendían las finanzas locales del duque se produjo precisamente en aquellos años de apuro, allegando fondos para la agencia de Madrid, donde entregó 1.000 ducados $^{32}$. Su valedor, Dávila, tuvo que dar la cara por él en sus primeros y poco firmes pasos como tal proveedor. En diciembre de 1630 Dávila escribió a Liébana dando cuenta de la pesadumbre con que quedaba Novela por haber salido incierta una partida de 2.000 ducados que debía remitir a la condesa de Tendilla en concepto de pensión para el conde de Saltes — sobrino y tutelado del duque. Fruto de este fiasco fue que Medina Sidonia mandase «prenderle». Dávila defendió a Novela, quien aseguraba que si lograban hacer buena aquella partida evitaría en adelante nuevos contratiempos. Aseguraba Dávila que «don Fernando es buen caballero, pero alcanzado, limpio y apurado. Vuestra merced le ayude por su parte» ${ }^{33}$. No cabe duda de que aquellos problemas se solventaron, porque unos meses después se repitió la libranza de 1.000 ducados de Novela a la agencia, para alegría del contador mayor del duque, que decía holgarse de lo bien que se entendían proveedor y agente ${ }^{34}$. Aunque no conocemos la naturaleza de los negocios de Novela en Madrid -muy probablemente fuese tratante de salazones-, lo cierto es que sus negocios con la Corte precedieron a su aparición como proveedor de la agencia, aunque al cabo compaginase ambas actividades.

Pese a todo, el problema de la financiación de la agencia a principios de los años de 1630 parece que llegó a ser poco menos que insoluble. En carta al agente del duque en la Corte, el contador mayor lamentaba mucho tener el dinero en su poder para remitírselo pero no encontrar los medios de hacérselo

\footnotetext{
31 ADMS, leg. 3.063, carta sin fecha, de 1630, probablemente de abril.

32 ADMS, leg. 3.063, cartas de 16 de marzo y 12 de octubre de 1630.

33 ADMS, leg. 3.063, carta de 22 de diciembre de 1630.

34 ADMS, leg. 3.063, carta de 6 de julio de 1631.
} 
llegar desde Sevilla. Tanto era así que el mismo Dávila, que se envanecía de sus contactos, tenía que solicitar a Liébana que buscase los medios para encaminarlo "con los mercaderes de ahí», puesto que en Sevilla no querían remitirlos si no era con un 5 ó $6 \%$ de interés, lo cual no quería hacer sin el consentimiento de los destinatarios finales del dinero - la condesa de Saltes y el Patriarca de las Indias ${ }^{35}$.

Con respecto al mantenimiento del conde de Niebla en Madrid, cuyo costo era muy alto, en 1635 el duque buscó la forma de que el rey le diese una ayuda de costa. En este sentido, se dirigió a su agente para tratar de «arbitrar las ayudas que mi hijo ha de tener para perseverar ahí o los modos con que volver con decencia a su Casa». Alegaba el duque para esa merced los muchos gastos a los que se había visto obligado en servicio del rey, junto con las pérdidas provocadas por la guerra. Como argumento de peso, el duque recordaba que «todo el mundo sabe que mi aduana era la mayor renta de mi mayorazgo, pues hoy la daré toda a mi hijo para sustentar[se] con ella, con que se verá y conocerá el fundamento de mi sobrevenida imposibilidad». Debía dar cuenta el agente no sólo a su hijo, sino también al conde-duque, del ruinoso estado de su hacienda, que le estaba obligando a dilatar gastos tan obligados como la dote de la entonces duquesa de Bragança. Al fin, se ufanaba de vivir «muy presumido de que en toda ella [mi vida] no merezco censura sino muchas gracias» ${ }^{36}$. Su muerte, ocurrida unos meses después, obligó al regreso de su hijo, reduciendo así los costes que para las finanzas ducales suponía el mantenimiento de dos casas.

\section{LOS TRIBUNALES DEL REY: LOS GRANDES PLEITOS}

La primera actividad de la agencia en volumen de documentación generada y la más constante y reglamentada era, sin duda, el seguimiento de los pleitos de los duques de Medina Sidonia en los más altos tribunales reales. En esta actividad, al menos en teoría, la agencia funcionaba como un órgano colegiado. Sin embargo, las reiteradas órdenes emitidas desde Sanlúcar para que las juntas de letrados en Madrid conociesen mancomunadamente los pleitos, que al parecer no eran obedecidas, nos informan sobre importantes aspectos del funcionamiento de la agencia. Para Medina Sidonia, en primer lugar, el objeto principal de estas reuniones era que, en caso de que quien llevase una causa cayese enfermo o hubiese de ausentarse, otro abogado pudiera tenerla entendida para seguirla en su lugar, evitando pérdidas graves por la no comparecencia en algún trámite. También se trataba de una forma de que los abogados en la Corte se controlasen mutuamente ${ }^{37}$.

\footnotetext{
35 ADMS, leg. 3.063, carta de 24 de noviembre de 1631.

36 ADMS, leg. 3.083, carta de 28 de octubre de 1635.

37 En 1628, en un momento en el que no había agente estable, sino que se abrió un breve lapso desde el cese de uno hasta la llegada del nuevo, Medina Sidonia ordenó al enviado especial — fray Alonso
} 
Por su parte, la elaboración de la estrategia jurídica corría en paralelo a cargo del consejo ducal en Sanlúcar y de los abogados de la agencia de Madrid, siempre contando con el criterio y aprobación final del duque, dando lugar a una duplicidad de hecho en la función de dar consejo al señor. Esta duplicidad no implicaba equivalencia entre ambos organismos asesores, dado que la participación del consejo ducal tenía un marcado carácter de control de la actividad de los letrados madrileños. En este sentido, en ocasiones podía ser enviado un letrado del consejo del duque para hacer una reunión extraordinaria de abogados y tratar de resolver algún asunto judicial particularmente complejo. Este fue el caso de fray Nuño González Nacelo, quien en 1628 fue remitido por el duque a Madrid con este fin, donde se ocupó de armonizar tanto el aspecto jurídico — preparación de la defensa del duque - como el extrajurídico — visitas a los jueces a sus casas para tratar de granjear su favor- en un momento en el cual se esperaba una sentencia inminente ${ }^{38}$.

Esta distinción que hemos apuntado entre los dos modos posibles de influir sobre una sentencia — jurídico-argumentativo o mediante la prevaricaciónresulta esencial para entender el cometido de la agencia en Madrid, que la convierte en esta materia en algo más que una junta de abogados. Dos eran las formas por medio de las cuales los agentes podían orientar la voluntad de los jueces más allá del derecho: bien recurriendo a la presión política — destacando la importancia estratégica de la labor de la Casa ducal en la Baja Andalucía como argumento para el mantenimiento de su posición de privilegio- o bien por medio del soborno. En general nos encontramos con situaciones híbridas, siendo preferente el primer medio con los jueces de mayor rango y el segundo con los oficiales de los juzgados. No debemos dejar de reparar, en todo caso, que en las visitas a los jueces existía una cierta gradación ritual, según fuese la importancia de la causa de que se tratase. En las ocasiones más graves se disponían verdaderas comitivas en las que se echaba mano de todos los recursos de presión en la Corte, haciendo comparecer en ellas a conspicuos miembros del clan familiar en Madrid ${ }^{39}$.

En el periodo que nos ocupa encontramos tres pleitos de suma importancia para la Casa seguidos en diferentes Consejos. Debido a su complejidad y larga duración, entre los tres absorbieron la mayor parte del esfuerzo jurídico de la agencia. La diversidad de las materias sobre las que versaban nos ofrece una muestra de la adaptación, según los niveles de negociación, de las estrategias jurídicas y de presión empleadas por los Medina Sidonia. Así, el pleito de las alcabalas, iniciado con la Real Hacienda, que acabó degenerando en un enfren-

Nuño- que reuniese a los cuatro abogados entonces al servicio del duque para conocer de cierto auto. ADMS, leg. 3.063, carta de 21 de mayo de 1628.

38 ADMS, leg. 3.063, carta de 25 de junio de 1628.

39 En 1635, por ejemplo, en vísperas de la determinación del pleito de la sal, el duque dispuso la visita a los jueces, para hacer entrega de las alegaciones, del agente acompañado del Patriarca de las Indias y del conde de Niebla, heredero del ducado. ADMS, leg. 3.083, carta de 18 de noviembre de 1635 . 
tamiento con los vasallos, situó al duque en una delicada situación típicamente señorial, tratando de evitar que los intereses de Corona y súbditos coincidiesen en exceso. El pleito del banco de los Espinosa, por su parte, situó al duque en la difícil situación de evitar un enfrentamiento abierto con Olivares, cuyo ascenso obligó al duque a retirarse de la causa. Por fin, el pleito de la sal enfrentó al duque con la propia voluntad reformadora de la Corona.

El pleito de las alcabalas de Jimena, Medina Sidonia y Vejer (lugares del estado ducal de la Fronter ${ }^{40}$ ) se desenvolvió en el Consejo de Hacienda desde que el fiscal pusiera demanda en 1612 a la totalidad de las alcabalas percibidas por los Medina Sidonia en sus estados. Tras las primeras diligencias y mediando una información jurídica amplísima presentada por el duque a favor de su derecho, fue la intervención directa de Lerma la que facilitó que el pleito fuese sobreseído el 9 de marzo de 1615 por lo que tocaba a todos los lugares del duque, con excepción de los mencionados ${ }^{41}$. Reducido a estos lugares el pleito, el principal argumento utilizado por los abogados del duque fue la inmemorial posesión del disfrute de esta renta por su Casa sin que mediara más derecho que la "permisión de Su Majestad», aunque fuese comprendida la renta de la alcabala en el concepto de almojarifazgo, «según el uso y costumbre de aquella tierra», tratando de demostrar así que ambos conceptos eran la misma cosa ${ }^{42}$.

Esta causa, que en principio enfrentaba al duque con el fiscal, no era en modo alguno ajena a la relación del duque con sus vasallos, cuya iniciativa trató de controlar el duque. El temor de don Manuel Alonso era que la intervención de la justicia regia «resabiase»-la expresión es del duque en carta a su agente- a los vecinos. Resabiarse significaba en aquel contexto que los vecinos percibiesen que la oportunidad era adecuada para hacer que su justicia prevaleciese de algún modo sobre la del duque. Había diversas formas de evitar que tal cosa se produjese, la primera de las cuales era el adecuado manejo de los argumentos jurídicos alegados, evitando que la cuestión se desviase de lo que al duque importaba demostrar. Para ello, por ejemplo, se debía orientar la elaboración de las informaciones de testigos ${ }^{43}$. En palabras del duque era «menester articularlo con artificio» de modo que ante todo quedase probado el derecho de

\footnotetext{
${ }^{40}$ Esta denominación bastante imprecisa incluía la ciudad de Medina Sidonia, Vejer, Conil y Chiclana, además de los dos pueblos de la serranía de Ronda, Jimena y Gaucín.

${ }^{41}$ ADMS, leg. 690. Información hecha en 23 localidades con testimonios de multitud de testigos.

${ }_{42}$ ADMS, leg. 779, el decreto mencionado data de 1615. Todo ello resumido en un memorial impreso de 1619.

${ }_{43} \mathrm{El}$ agente Escobedo sugirió que se pusiese de manifiesto que todas las exenciones de los lugares eran fruto de la merced ducal, a lo que se opuso el consejo ducal argumentando que aquello favorecería más a los vecinos que al duque, por lo que resultaría más conveniente defender que era privilegio real el no pagar alcabala de lo labrado y criado por los vecinos. Don Manuel Alonso, por otro lado, aprobaba la opinión del agente de no incluir en la demanda judicial la cuestión de las alcabalas de segundas ventas, porque si el juez era «cuidoso» perjudicaría su derecho. ADMS, leg. 2.949, 10 de abril de 1616.
} 
los duques y no la exención de los vejeriegos. A tal efecto, la prioridad era buscar testigos que depusiesen lo que se pretendía probar ${ }^{44}$.

Sin embargo, con la entrada de algunos representantes de los vasallos como parte independiente en el pleito, el duque recurrió a diversas fórmulas para hacerles desistir de su causa. En primer lugar, en un momento especialmente complicado, don Manuel Alonso aconsejó que se quitase de la causa "por mano ajena» a Francisco de Escobar - representante de la ciudad de Medina Sidonia-, ya que se le vinculaba con los que son "conocidamente inquietos» del lugar ${ }^{45}$. Cuando, años después, se iba entreviendo que se acercaba la resolución de la causa en el Consejo y que era la ciudad de Medina Sidonia la que mejor parecía situada, don Manuel Alonso trató de asfixiar económicamente a los agentes de la ciudad menos afectos a su Casa. Para lograrlo consideraba que sería «muy a cuento se les quitasen los socorros de dinero que sacan de las dehesas para los pleitos; de nuestra parte se asista al procurador de la dicha ciudad y coadyuvadle en lo que nos estuviere bien ${ }^{46}$. La diferencia de trato con el emisario concejil dependía, por tanto, de su acomodo a los intereses del señor.

Por otra parte, jugar con los tiempos de un pleito - acelerándolo o ralentizándolo por medio de sobornos- podía ser también vital. Valga de ejemplo lo que el duque escribió en agosto de 1623 a su agente, aprobando lo tratado con un oficial del Consejo por cuyas manos pasaba el pleito de las alcabalas, diciendo «que fue bien obligarle a esto con darle los 200 reales que me decís que le dísteis, que como os he dicho importa tenerle ganado para que el memorial se entretenga ${ }^{47}$. No menos importante podía ser intervenir en la localización del pleito en según qué tribunales — y hasta en según qué salas - en función de las expectativas de éxito. Había que evitar que un «juez quebrantahuesos» —en palabras de un agente del duque en Granada- pudiera dar muchos quebraderos de cabe$\mathrm{za}^{48}$. De hecho, la Chancillería de Granada era estimada a fines de los años 1620 por el duque como un tribunal difícil, al cual se debía estorbar la remisión de autos desde Madrid por la mala experiencia que se tenía, sobre todo cuando se trataba de la determinación definitiva de una causa, llegándose en ocasiones a la recusación del tribunal ${ }^{49}$.

${ }^{44}$ Se tenía la experiencia de una probanza anterior en la que los testigos habían aludido a un privilegio real cuya mención, al no haber sido encontrado el documento, resultaba improcedente. ADMS, leg. 2.949, 22 de mayo de 1616.

45 ADMS, leg. 2.949, carta de 10 de abril de 1616.

46 ADMS, leg. 3.001, d. 221, carta de 1 de octubre de 1623.

47 ADMS, leg. 3.001, d. 195, carta de 21 de octubre de 1623.

${ }^{48}$ La expresión utilizada por el licenciado Francisco Cisneros —agente en Granada- para referirse al oidor Carvajal fue la de que daba «humazos de día y de noche», en carta de 7 de noviembre de 1628 al agente Liébana. ADMS, leg. 3.063.

49 Así lo ordenó el duque en 1628, cuando se esperaba un auto de traslado del pleito de las alcabalas desde el Consejo de Hacienda a la Chancillería. Carta a fray Alonso Nuño. ADMS, leg. 3.063, 21 de mayo de 1628. 
El soborno más o menos encubierto que parece haber sido ampliamente utilizado, figura en las cuentas bajo la fórmula de gastos secretos o justificados como de orden expresa del duque. Excepcionalmente encontramos cuentas en las que se aclara el destino de dichos gastos. Así sucedió cuando el contador mayor del duque solicitó al padre fray Ignacio Yáñez que aclarase algunos puntos de las cuentas que éste había presentado de su comisión extraordinaria en Madrid y Granada. Lo que salieron a relucir entonces fueron cuatro partidas con las que el agente había tratado de comprar varias voluntades. La primera cifra era un pago de 50 reales a un oficial del secretario Palencia, a quien, comentaba el fraile, «conviene tener contento, como el duque mi señor me lo ha mandado en muchas cartas, porque ante él pasan todos los pleitos de Vejer y Medina». La última partida, también de 50 reales, se entregó a Pedro de Palomares como gratificación por una conversación en la que el tal Palomares había dado a entender a Yánez que el fiscal trataba de poner una nueva querella al duque. El mismo Palomares señaló que esto se podía evitar si se seguía su consejo, que era que Yánez «escribiese al duque mi señor [que] le mandase dar alguna cosa y haría que no se tratase más de ello». Al fin, comentaba Yáñez satisfecho de su gestión, «bien poca cantidad fue dar a un secretario de esta Chancillería 50 reales» ${ }^{50}$. Por su parte, el encargo de asesoramiento jurídico a jueces reales, cuyo monto se negociaba, apenas disimula la compra de la voluntad del juez que los debía ofrecer.

En todo caso, volviendo al asunto de las alcabalas, el fin de la mayor parte de los pleitos en la Edad Moderna no era alcanzar una sentencia definitiva, sino llegar a un acuerdo o concordia entre partes, muchas veces con la mediación de un árbitro, como fórmula para poner fin a causas que amenazaban literalmente con eternizarse. El pleito de las alcabalas no fue excepción a esta norma, al menos en lo que respecta a Vejer y Jimena, pese a lo confiado que había estado el duque en su justicia. Cierto vuelco que en pocos días había dado la materia, cuando parecía casi concluida en su favor, movió a don Manuel Alonso a escribir a su agente confesando que las novedades le habían «reducido a oír la plática de la transacción y concierto que el señor conde-duque los días pasados me propuso, como entenderéis de lo que escribo a Su Excelencia». La plática consistía en sustancia en la venta de las alcabalas al duque, quien remitió a su agente una copia de la propuesta de Olivares junto con una instrucción propia. La materia debía ser tratada entre el licenciado Altamirano y el propio Liébana con toda prisa, tratando de zanjarla cuando el pleito estuviese aún en fase de remisión, es decir, antes de que se determinase, pues de otra forma tendría peor estado ${ }^{51}$.

Esta negociación no excluía el abandono de otras formas de lograr una mejora en la situación. Así, mientras se avanzaba por una vía, el duque presionaba por todos los medios a los enviados de las villas para lograr que aceptasen el

50 ADMS, leg. 2.949, carta de 26 de marzo de 1619.

51 ADMS, leg. 3.063, Medina Sidonia a Liébana, 22 de octubre de 1628. 
acuerdo. Por entonces algunos votos particulares de vecinos impedían cerrar el trato, entre ellos el de don Gonzalo de Carvajal, vecino y representante de Vejer en Madrid, que no transigía en la concordia. Para sortear aquel escollo los abogados del duque aconsejaron a Su Excelencia que pidiese al Patriarca de las Indias, su hermano, que hiciese las diligencias oportunas en Madrid para que los jueces obviasen tal voto. Una vez individualizado el estorbo era más fácil poner en marcha medios para desautorizarle, para cuyo fin remitió Liébana a Sanlúcar unas «escrituras» que inculpaban en cierto delito a Carvajal ${ }^{52}$. Así, cuando en Granada se dictó una sentencia que excluía a este individuo del pleito, el propio Carvajal acudió a Sanlúcar a tratar con el duque. Medina Sidonia escribió entonces a su agente que «si él [Carvajal] ha salido ya de esa Corte, como me decís, y viene tan reducido, acá trataremos lo que convenga y estos negocios se van disponiendo de manera que mi justicia está tan entendida que, aunque no se [a]viniese, tengo por cierto que se ha de confirmar la transacción en que los vecinos de aquella villa han sido tan interesados y beneficiados». Ya en la corte ducal, Medina Sidonia no quiso recibir a Carvajal, dejándole tratar con los de su consejo, porque como señalaba el duque, aunque se le hiciesen mercedes, luego las olvidaba. Así, mientras Carvajal esperaba inútilmente ser recibido por su señor, se le estaban tomando cuentas en Vejer por malversación de los fondos de la villa destinados a los pleitos ${ }^{53}$.

Pese a este éxito y a la prisa del duque, la concordia se estancaba. Para entonces, preocupaba a don Manuel Alonso que «la indisposición del marqués de los Trujillos» aumentase los retrasos, dado que era tenido por juez proclive a la Casa. La desesperanza del duque crecía, "pues el fin de una resolución llama el principio de otra». Según Medina Sidonia, la voluntad de «todos» — se entiende que de los miembros de la sala_ era no «irritar» al rey, no admitiendo a discusión que la cuestión de las alcabalas era materia de gracia y no de compra, aspecto que era sustancial para la plenitud del derecho de posesión posterior de las alcabalas por el duque. Además, aquello tenía como negativa consecuencia práctica para Medina Sidonia, que los arrendadores de las alcabalas de sus villas interpretaban que el retraso de la concordia se debía a la falta de justicia del duque, por lo que alteraban el precio de los arriendos a la baja ${ }^{54}$.

La fijación del precio de la renta fue también materia controvertida. Frente a la valoración hecha por el fiscal —que el duque calificó de «quimera»—, Medina Sidonia urgió a la obtención de una dilación que le permitiese responder a los argumentos del fiscal, siendo una petición que «a nadie se niega en el mundo, por más que sea el aprieto de la Hacienda [Real], mayormente si se acabase de abrir los ojos para ver de la manera que yo gasto la mía en servicio de Su Majestad y en ahorro de la suya y de sus cuidados» ${ }^{55}$. La introducción del argumento,

\footnotetext{
52 ADMS, leg. 3.063, carta de 30 de septiembre de 1629.

53 ADMS, leg. 3.063, carta de 18 de marzo y 15 de julio de 1629.

54 ADMS, leg. 3.063, carta de 16 de septiembre de 1629.

55 ADMS, leg. 3.063, carta de 25 de junio de 1630.
} 
tan querido a la tradición auto-reivindicativa de la Casa de Medina Sidonia, del buen empleo en el real servicio de sus muchas rentas, suponía un intento de llevar la negociación al terreno más político de la vinculación de los Pérez de Guzmán con sus reyes. Pese a todos los esfuerzos, sólo tras la conjura de 1641 y la consiguiente alteración de esa relación, se feneció el pleito en el contexto del castigo al IX duque.

El pleito por la quiebra del banco de los Espinosa nos interesa aquí por cuanto enfrentó judicialmente al duque de Medina Sidonia con el entonces conde de Olivares. El contencioso generado por la sonada quiebra del banco hispalense implicó a buena parte de la aristocracia sevillana, muchos de cuyos negocios tocaban de algún modo a aquel banco ${ }^{56}$. El interés de Medina Sidonia y de sus hermanos se debía a que el duque don Alonso había dejado buena parte de sus bienes libres vinculados de una u otra forma a este banco. Así, del grado de prioridad que se diese a los duques como acreedores frente a los demás iba a depender que los hijos segundones del duque difunto recibiesen sus alimentos. Pero lo que hacía vidrioso el asunto era la concurrencia en la causa, con intereses opuestos, del nuevo favorito real y primo de don Manuel Alonso, el conde de Olivares. La sutileza debía marcar la acción del duque, por lo que todos los canales indirectos de negociación con el conde debían ser explotados, incluida la mediación de la condesa ${ }^{57}$. La prioridad de Medina Sidonia fue por tanto eludir el enfrentamiento, misión que quedaba encomendada al agente en Madrid. Así, en el otoño de 1623 el duque se mostró muy agradecido a Vallejo por la «buena maña» que se había dado «para que el señor conde de Olivares entienda cómo por mi parte ningún criado mío cuida del pleito de los Espinosas, en que yo no he querido tener nombre de litigante con Su Excelencia». La maniobra consistía en dejar que fuesen los abogados de los hermanos del duque los que litigasen, dado que lo hacían con acierto, siendo el agente del duque en Madrid sólo el suministrador de los fondos necesarios para la causa, a lo cual, por otro lado, estaba obligado el duque en cuanto que tutor de sus hermanos menores $^{58}$. Sin embargo, esta ficción no impedía al consejo del duque en Sanlúcar opinar y dirigir la estrategia jurídica del pleito ${ }^{59}$. En todo caso, cuando en octubre de 1623 Olivares pidió por su parte información en derecho sobre el estado del pleito, el duque se limitó a encargar al agente que los letrados fue-

56 Sobre los Espinosa, véase Lohman Villena, G.: Les Espinosa. Une familla d'homes d'affaires en Espagne, París, 1968; y Lorenzo SANZ, E.: Comercio de España con América en la época de Felipe II, Valladolid, 1986, tomo I, 256-261.

${ }^{57}$ Sabemos que en el verano de 1623 el duque encargó a su agente que tratase con ella ciertos puntos, mostrando siempre la buena disposición de Medina Sidonia hacia Olivares. ADMS, leg. 3.001, d. 257, 23 de julio de 1623.

58 ADMS, leg. 3.001, d. 195, carta de 21 de octubre de 1623.

59 No sólo se dirigían las estrategias, sino que se tasaron los convenios a los que se debía llegar con un consejero de Castilla para que sacase información jurídica. ADMS, leg. 3.001, d. 218, carta de 21 de mayo de 1623. 
sen respondiendo punto por punto a las alegaciones basándose en dos sentencias del Consejo Real, de lo que se prometía «muy buen suceso» ${ }^{60}$.

$\mathrm{Al}$ año siguiente, Medina Sidonia, ante la inminencia de la ejecución de la sentencia contraria a sus intereses — que debía efectuarse en Sevilla—, remitió orden a Vallejo para que buscase la forma de componerse con Olivares y quienes le llevasen los asuntos de hacienda, encontrando una fórmula por medio de la cual saliesen favorecidos en su paga los hermanos del duque, que andaban con poca comodidad para su sostenimiento. Para allanar la voluntad del valido, don Manuel Alonso recordaba al agente en una posdata de su puño y letra cuál era la baza más importante en esta materia, que consistía en recordar cómo el duque había procedido

«haciendo gracias al señor conde de Olivares del derecho que en él [el pleito] me pudiera tocar, $[y]$ no he permitido que por mi parte se haga diligencia ninguna ni se oiga mi nombre en esta defensa y hiciera lo propio con el de mis hermanos si estuviera a mi disposición».

De todo ello tenía el agente testimonios bastantes para demostrarlo ante el conde-duque y la marquesa del Carpio, también interesada en el pleito ${ }^{61}$. Por si quedaban dudas, cuando en octubre de 1625 , el duque fue informado de que un solicitador de sus hermanos pretendía recurrir cierta facultad obtenida por Olivares, Medina Sidonia dio orden a su agente de que le hiciese desistir para evitar que los abogados del valido tuviesen argumentos para indisponer a ambos primos ${ }^{62}$.

El tercer gran pleito de estos años, el de la sal, tiene un carácter más político que ninguno de los anteriores, al quedar descarnadamente enfrentada la voluntad regia con un derecho señorial. Los antecedentes databan del momento en el que Felipe II dispuso la reserva de la explotación de todas las salinas castellanas en concepto de regalía, con excepción de las salinas de Andalucía, sobre las cuales se impuso el pago de una tasa a las ventas ${ }^{63}$. Esto afectó al duque en varios sentidos, el primero de los cuales era como productor. Pero además, la necesidad de grandes cantidades de sal para sus almadrabas, de las que disfrutaba con privilegio de exclusividad y libre de cargas, ofrecía un complejo dilema jurídico al quedar confrontadas la gracia regia de la concesión del privilegio con el derecho de regalía. Tras varias fases se llegó en 1575 a una concordia, por virtud de la cual el duque compró el derecho de explotar y extraer hasta 5.000 cahíces de sal anuales para sus pesquerías ${ }^{64}$. Ahora bien, ese acuerdo no impidió que siguiesen produciéndose reaperturas del pleito, sobre todo porque

${ }^{60}$ ADMS, leg. 3.001, d. 221, carta de 1 de octubre de 1623.

${ }^{61}$ ADMS, leg. 3.001, d. 292, carta de 7 de julio de 1624.

62 ADMS, leg. 3.001, d. 444, cartas de 14 y 26 de octubre de 1625.

${ }_{63}$ Gelabert, J.E.: Castilla convulsa (1631-1652), Madrid, 2001, pp. 17-66.

${ }^{64}$ Compra que incluyó siete dehesas en Jimena de la Frontera, todo lo cual alcanzó el monto de 300.000 ducados. 
una de las formas de venta de atún por parte del duque era semielaborado, con el suplemento de sal necesaria para la definitiva sazón del atún — para terminar el proceso conocido como «beneficio». Por este canal, según denunciaron los ministros reales, se ocultaba la venta directa de sal sin pagar derechos.

Después de que en 1626 las Cortes de Castilla aumentasen el precio de la fanega en dos reales, Medina Sidonia fue mudando su estrategia de defensa que perseguía tres objetivos. Primero, obtener no sólo el reconocimiento de su derecho a fabricar 5.000 cahíces de sal — que él daba por supuesto-, sino el de la venta de la sal «en ser» para el beneficiado ${ }^{65}$. En segundo lugar, la cuestión de la tasa de la sal, asunto que preocupaba al duque ya que «si la mayor parte de ellos [los procuradores] la resuelven con la voz que se ha dado de lo que vale este derecho, como hoy corren las cosas, han de ponernos en cuidado». Se temía que si al fin se debía pagar tasa por la sal para beneficiar, el atún sería difícil de colocar en el mercado. Por eso, lo importante era obtener resolución en términos de justicia en el Consejo de Castilla y que éste «lo mandase al reino» ${ }^{66}$. Al fin, en agosto de 1629 , el duque y su consejo se conformaron con cerrar por la vía rápida el asunto aceptando el reconocimiento de su justicia en lo principal, esto es, la cláusula que aseguraba que no se podría en adelante imponer derechos sobre los 5.000 cahíces $^{67}$.

Sin embargo, en 1631 se puso en marcha el proyecto de la contribución única de la sal, que despertó una serie de protestas en toda la Corona de Castilla, desde Sevilla a Guipúzcoa ${ }^{68}$. El duque salió de inmediato a defender su justicia en lo general, aunque la preocupación más inmediata era no poder contar con la cantidad de sal necesaria para las pesquerías del año siguiente, dado que la almadraba se montaba en primavera ${ }^{69}$. Por entonces el doctor don Pedro Díaz Noguerol realizó, por encargo del duque, unos apuntamientos sobre el «derecho sumarísimo» que el duque entendía que le asistía, ya que don Antonio Chumacero le había «turbado e inquietado» en la posesión de gozar de la franqueza que tenía por merced regia. El duque entendía que en consecuencia de aquellos argumentos no quedaba otra vía al Consejo que «dar a entender mi justicia en los estrados y a los jueces en sus casas». Por ello, además, el agente debía solicitar con todo fervor que se votase en el nuevo tribunal específico, el Consejo de la Sal — creado en abril de $1631^{70}$ —, a tiempo de tenerlo resuelto para la almadraba siguiente ${ }^{71}$.

En este caso, los agravios de los concejos de los estados del duque coadyuvaban a la justicia de su señor. Entre ellos figuraba Sanlúcar de Barrameda,

\footnotetext{
65 ADMS, leg. 3.063, carta de 29 de octubre de 1628.

66 ADMS, leg. 3.063, carta de 15 de julio de 1629.

67 ADMS, leg. 3.063, carta de 5 de agosto de 1629.

68 GelaberT: Castilla convulsa..., 36-66.

69 Don Lorenzo Dávila a don Gaspar de Liébana. ADMS, leg. 3.063, carta de 15 de marzo de 1631.

70 GelaberT, J.E.: La bolsa del rey. Rey, reino y fisco en Castilla (1598-1648), Barcelona, 1997, 86.

71 ADMS, leg. 3.063, carta de 20 de junio de 1631.
} 
quejosa del repartimiento de sal que se le había hecho por el alcalde enviado a tal efecto. El agravio de los cabildos era doble: por un lado, se argumentaba la contravención de lo acordado por ellos con el licenciado don Antonio de Chumacero cuando había ido a asentar el valor de la contribución; por otro, se quejaban de que no se les hubiese tomado en cuenta el exceso que habían pagado en concepto de lanzas - haciendo la pertinente reducción-, como también se acordó con los administradores de la sal. Además, el duque se refería a ciertos agravios comparativos con otros concejos de la zona que habían obtenido algún tipo de respuesta, frente al silencio que imperaba en lo tocante a sus vasallos. Por todo ello, el duque encargó a su agente, Pedro de Robles, que amparase en esta ocasión «muy de veras» a sus vasallos en Madrid ${ }^{72}$.

$\mathrm{Al}$ año siguiente, la parte del duque se desesperaba de la falta de decisión del Consejo de la Sal en la determinación en su pleito, sobre todo una vez más en previsión de las necesidades de abasto de las almadrabas, que ya ponían en peligro que se pudiesen armar. Los temores del duque se fundaban en que si recurría de nuevo a la licencia que el año anterior le había sido otorgada, ésta fuese a precios tan elevados «que no lo pagase yo con el valor y procedido del almadraba». Ponía así en consideración de los abogados de Madrid el procedimiento más adecuado para obtener licencia por menor precio del que se daba a otros pescadores — que era a 29 reales la fanega—, porque los tales no tenían «el privilegio que yo ni les ha costado tantos ducados como a mi Casa». Todo ello se reforzaba con el argumento más general empleado por el duque en la causa, según el cual el decreto de 3 de enero de 1631 no le incumbía ${ }^{73}$.

Pese a que el experimento de contribución única concluyó dos años después, los litigios del duque por la venta de sal en ser prosiguieron. En agosto de 1635 la parte del fiscal pidió hacer una probanza, de la cual el duque decía no temer gran cosa, por lo que se extrañaba de que la junta de sus abogados en Madrid hubiese estimado necesario contestar a los argumentos del fiscal. No obstante, admitía que si todos lo entendían así, se redactase una alegación por parte del licenciado Noguerol y que se llevase a la imprenta ${ }^{74}$. El duque, por su parte, preparó con su consejo en Sanlúcar su propia probanza, proceso en el que se produjo algún roce con el agente, a quien el duque reprochó no haber consultado a tiempo las diligencias para nombrar comisionados para hacer el cuestionario $^{75}$. En efecto, nada pareció salir probado del interrogatorio del fiscal, en opinión del duque, por lo que urgía a su agente a que presionase para que se determinase la causa de una vez, porque ni aún suponiendo una sentencia en contra le estaba bien la dilación, toda vez que las salinas con las que pro-

72 En febrero de 1632 se sumaron los concejos de Medina Sidonia, Vejer, Chiclana, Trigueros y Trebujena a la querella contra los administradores de la sal. ADMS, leg. 3.063, 13 de julio de 1631 y 22 de febrero de 1632 .

73 ADMS, leg. 3.063, carta de 22 de febrero de 1632.

74 ADMS, leg. 3.083, carta de 10 de junio y 12 de agosto de 1635.

75 ADMS, leg. 3.083, carta de 29 de febrero de 1635. 
veía sus almadrabas quedaban embargadas ${ }^{76}$. En enero de 1636 , meses antes de su muerte, el duque ordenó hacer otra junta a sus abogados con presencia del conde de Niebla para preparar una vista que se iba a hacer en el pleito, mientras se trataba, una vez más, de evitar que el arrendador de la sal o su agente interpusiesen obstáculos en el abasto de sal para la almadraba de aquel año ${ }^{77}$.

\section{LAS MATERIAS DE ESTADO Y GUERRA}

Los modos específicos de acceso al rey de los sucesivos duques difieren en varios sentidos. En primer lugar por los cargos ocupados. Así, desde que el VII duque don Alonso fue nombrado Capitán General del Mar Océano y Costas de Andalucía en 1588 y mientras la Casa ostentó tal dignidad -hasta la conjura de su nieto en 1641-, el acceso a los Consejos de Estado y Guerra de los duques era el de un general en ejercicio, tendiendo en lógica consecuencia a quedar canalizada por esta vía buena parte de la correspondencia formal con el rey. Desde 1599 el VII duque y desde 1624 el VIII, a esta dignidad sumaron la de ser miembros, aunque en la distancia, del Consejo de Estado, lo que les permitió tomar parte de una forma más estable en las reuniones y consultas de este selecto órgano asesor por mediación de memoriales. Estas dignidades y reconocimientos formales eran a la vez consecuencia del poder de la Casa y cauces por medio de los cuales su influencia se dejaba sentir en la Corte real. Ahora bien, los Consejos eran filtros de acceso al rey por los que pasaban propuestas, quejas y memoriales de todo tipo. Un cierto asunto que Medina Sidonia quisiera ver tratado en un Consejo - para lo que enviaba una carta o memorial — pasaba, en principio, por un doble filtro. Primero, el de un secretario o un valido, a cuyo arbitrio quedaba la inclusión del asunto en un puesto determinado en el orden de tramitación o no incluirlo. El segundo filtro era la propia reunión del Consejo.

Los Consejos también podían llegar a ser en determinadas ocasiones un estorbo para el logro de un fin concreto. Así, hacer que la opinión del duque llegase al lugar y en el momento que era preciso podía ser vital, de modo que los contactos cortesanos del duque - de los que nos ocuparemos más fondo en el siguiente apartado - eran ampliamente empleados en el tratamiento de las materias bélicas ante el rey. La utilidad de este sistema dependía mucho del grado de afinidad de cada duque a la orientación política del rey y su privado en cada momento. Paradójicamente, pese a la importancia crucial del cometido

76 ADMS, leg. 3.083, carta de 2 de diciembre de 1635.

77 ADMS, leg. 3.083, carta sin fecha, de enero de 1636. Por otro lado, según el texto de unas condiciones de arrendamiento de las salinas de Andalucía, el pleito siguió abierto hasta que en 1648 se sentenció que el duque pudiese extraer libre de derechos la sal pero, en lugar de fijar una cantidad, quedaba supeditado a las cantidades que pudiese demostrar haber consumido en sus almadrabas. ADMS, leg. 2.157, d. 594, septiembre de 1648. 
del agente - y no tanto de la agencia - en este aspecto, debemos señalar que, a diferencia de los asuntos judiciales, su participación en la sustancia de las cuestiones de política y milicia era más modesta o a veces nula. Así, en ocasiones, los agentes sólo ejercían de receptores y distribuidores del correo ducal, sin conocimiento del negocio que contenían los despachos. Sin embargo, por lo general eran informados con detalle de lo que se pretendía con el objeto de facilitarles la labor de mover las voluntades adecuadas en el sentido deseado.

En todo caso, una coyuntura especialmente delicada para un señor ausente de la Corte era el cambio de reinado, situación en la que resultaba fundamental mantener bien ajustados los contactos ${ }^{78}$. Al morir Felipe III, Medina Sidonia reforzó la agencia de Madrid enviando a su agente en Sevilla a la Corte con ciertas instrucciones especiales, encargando a don Juan de Castro - a la sazón agente en la Corte- que se comunicase con él ${ }^{79}$. La primera preocupación del duque fue mantener la buena disposición de los secretarios por medio de regalos. Para ello Medina Sidonia remitió una docena de cuñetes de atún con la indicación al agente de a quién debía repartirlos, en este caso los secretarios Bartolomé de Anaya y Pedro de Arce. Castro debía asegurarles también que «con la voluntad que les envío esta menudencia les serviré en las cosas de consideración que se ofrecieren y yo entendiere ser de su gusto» ${ }^{80}$. Importa destacar que antes de que Olivares consolidase su poder en la Corte Medina Sidonia reconociese el protagonismo de los secretarios, acaso por su previsible mayor estabilidad en el cargo. Como recordara algo después un agente al duque,

«es bien tenerlos contentos, porque son quien recuerda los despachos que se han de llevar al Consejo y poderosos para que se responda a ellos y el secretario se obliga con cualquiera gracia que se les haga» 81 .

Más allá de la prepotencia algo bravucona del agente, lo cierto es que la voluntad de los secretarios se compraba, o al menos una buena parte de ella.

Un secretario podía ser útil al duque para pasar por encima del Consejo. De tal modo, cuando el asunto era especialmente relevante, Medina Sidonia podía encargar al agente que recurriese al acceso directo al rey que disfrutara un secretario para convencer a Su Majestad de la conveniencia de tomar una u otra resolución particular. En 1622, Medina Sidonia remitió a Madrid a don Diego de Arce — gentilhombre de su cámara— con una carta para Su Majestad «por

${ }_{78}$ Por desgracia, los legajos de la agencia de Madrid son muy parcos en lo que respecta a información politica en el periodo 1615-1621, por lo que no podemos saber el papel concreto que desempeñó cada agente en las materias que entonces se trataron. Por eso, he preferido dejar fuera del presente apartado este periodo.

79 Debía además el agente en la corte financiar al agente de Sevilla el luto por el rey difunto. ADMS, leg. 3.001, d. 44, carta de 27 de abril de 1621.

${ }^{80}$ ADMS, leg. 3.001, d. 29, carta de 9 de julio de 1621.

81 ADMS, leg. 3.001, d. 81, carta de 8 de agosto de 1623. 
la vía de Juan de Ciriza» — secretario de guerra - para tratar el asunto de un embargo de navíos ejecutado por el duque en Sanlúcar sobre el que tenía particular interés. Lo que entonces buscaba Medina Sidonia era tratar lo más directamente posible con el propio Felipe IV para que «Su Majestad me haga merced de tomar en él resolución, mandándome lo que he de hacer». La respuesta del agente fue remitir, dos semanas después de que Arce saliera de Sanlúcar, una misiva a toda diligencia - que cubrió el trayecto Madrid-Sanlúcar en apenas tres días y medio - con la respuesta del rey por mano del mismo Cirizia ${ }^{82}$. No debemos dejar de reparar en el poder que un comportamiento de este tipo reconoce a un secretario, y más si atendemos a la condición de Ciriza de bechura de Lerma ${ }^{83}$.

Aún en 1623, cuando el duque ordenó a su nuevo agente que hiciese una ronda de visitas a algunos ministros como forma de sondear los apoyos y simpatías con los que contaba el duque en la Corte y para algunos otros fines mucho más concretos, la instrucciones más apretadas se referían a los secretarios. Primero, el agente debía procurar acercarse más a Bartolomé de Anaya — secretario de guerra en la parte de tierra - para lograr mayor «puntualidad» por su parte, estrechando su obligación con el duque sin perder su amistad. En especial, el duque recordaba la importancia de este secretario para la que era entonces su preocupación esencial: la defensa de Cádiz. Este cuidado se traducía para Medina Sidonia en la necesidad de asentar definitivamente la competencia de su mando militar en toda la costa en lo tocante a provisión de los cabos - capitanes y sargentos- de las compañías de Cádiz, para lo que el duque no dejó de usar toda la información de la que pudo disponer sobre antecedentes de nombramientos hechos por el duque don Alonso ${ }^{84}$. Un segundo objetivo era que se dictase una cédula en la que se garantizasen los privilegios de los miembros de la milicia de la costa, sobre lo cual aseguró Anaya que hablaría al presidente de Castilla, además de ir haciendo relación de ello en el Consejo. Señalemos que este arbitrio, no muy original en su espíritu, suponía dar forma concreta a un plan de reforma que se ha solido atribuir en exclusiva a Olivares.

En tercer lugar, Medina Sidonia pretendía de Vallejo que cimentase entre los ministros reales la conciencia de que la defensa de Andalucía debía ser prioritaria. Por medio del reconocimiento del peligro en aquella región, el duque buscaba aumentar su autoridad, presentada como garantía de defensa. En este caso Medina Sidonia quería que las armadas de galeras, del Estrecho, del Mar Océano y las milicias de Sevilla y otras ciudades del distrito de la Capitanía tuviesen la obligación de acudir a las fronteras — es decir, a la costa andaluza y los

82 Arce iba a percibir el elevadísimo salario de 20 ducados diarios el tiempo de su misión, a lo que se añadían 1.000 de premio si salía airoso. ADMS, leg. 3.001, d. 147 y 149, carta de 2 y 23 de enero de 1622.

${ }^{83}$ Feros, Antonio: El duque de Lerma. Realeza y privanza en la España de Felipe III, Madrid, 2002.

${ }^{84}$ Así, ordenó al agente en Madrid que hiciese memoria de todos los cargos de este tipo provistos en tiempos de su padre. ADMS, leg. 3.001, d. 251, cartas de 1 de marzo de 1623. 
presidios del norte de África - mediando sólo el llamamiento del duque, con el objeto de evitar peligrosas situaciones de incertidumbre en caso de ataque. Como ya había precedentes en este sentido, lo que había que lograr era que se refrescasen tales órdenes. En resumen, Vallejo decía estar recordando en la Corte

«el conocido riesgo a que están [esas costas] y lo mucho que Vuestra Excelencia hace y trabaja en conservarlas y alentar lo de ahí, sin que haya un real para nada, y que en lo que se ofrece gasta Vuestra Excelencia los suyos, sin que por acá se tenga constancia ni se estime ni agradezca y otras cosas que por un oído les entra y por otro les sale» 85 .

Esta alusión al desinterés de los consejeros no venía sino a afirmar lo que parece haber sido la sensación del duque de que los Consejos eran por entonces inoperantes, al menos para los fines que él perseguía. Por eso las gestiones de Vallejo con Anaya y otros ministros de más autoridad esperaban suplir a los Consejos $^{86}$. Peor aún, citando al mismo Anaya, el agente recordó al duque que «cada uno de los generales tiene su valido dentro del Consejo». Esta advertencia había sido empleada por el secretario para justificar que se hubiesen dejado de proveer de gente recientemente los presidios, tal y como había sido solicitado por Medina Sidonia. El duque agradeció la información porque así, según él, se comprobaba que el obstáculo que entonces vieron los consejeros no fue la utilidad de la provisión de hombres, sino el hecho de que la distribución de tropas se hiciese por su mano, comentando irónico

«como que yo tengo en esto alguna pretensión más que el servicio de Su Majestad y defensa de sus plazas y mira de mi propia obligación, que mira al remedio, no a las circunstancias ni ceremonias. Será bien que se entienda así y que a ellos [los consejeros] se les advierta».

De esta forma también se exculpaba Medina Sidonia de responsabilidad de los malos sucesos que se pudiesen derivar de tales omisiones ${ }^{87}$. De todos modos, pese a este desdén bastante explícito por los consejeros, tampoco podemos dar por sentado que el duque desatendiese su amistad, ya que de hecho conservaban su parcela de poder. Por eso, cuando algún nuevo consejero entraba en el de Guerra, el duque ordenaba a su agente que tratase con ellos, les diese la enhorabuena y tantease su disposición, anteponiendo la mejor posible de parte de su señor ${ }^{88}$.

85 Vallejo a Medina Sidonia, 8 y 10 de mayo de 1623; ambas respuestas del duque de 27 y 28 de mayo de 1623, desde Conil. ADMS, leg. 3.001, d. 81, 82 y 260.

${ }^{86}$ Había encargado el duque por entonces a Vallejo que tratase con el presidente del Consejo de Castilla la necesidad de proveer en un hombre de capa y espada el corregimiento de Jerez para que le ayudase en caso de ataque, proponiendo Medina Sidonia a don Diego de Escobar como sustituto del anciano Fernando de Quesada. ADMS, leg. 3.001, d. 222, carta de 22 de octubre de 1623.

87 ADMS, leg. 3.001, d. 260, carta de 28 de mayo de 1623.

${ }_{88}$ En septiembre de 1623 fueron don Luis Bravo y don Melchor de Borja. ADMS, leg. 3.001, d. 262, carta de 1 de octubre de 1623 . 
Las gestiones de Vallejo con Bartolomé de Anaya dieron resultados satisfactorios para el duque, que así se lo reconoció a su agente. A Vallejo atribuyó el duque el cambio de tono en la buena correspondencia del secretario, que aunque Anaya «está obligado a tenerla buena y hacernos amistad [decía el duque], suele esto entibiarse y estragarse según el cuidado que se pone en acariciar esos ministros; y advertidme a mí en lo que pueden estar cómodos». Por entonces, se pudo traducir esa comodidad de Anaya en algo concreto, como fue buscar la forma de anticipar una ayuda de costa que el rey tenía concedida a un oficial de su secretaría sobre bienes embargados por mano del duque, gestión que estaba paralizada y pendiente en el Consejo de Guerra. Con aquella información, el duque propuso adelantar lo que se debía al oficial, echando mano de ciertas resultas que habían quedado en Sevilla de otros embargos, gestión que ordenaba a su agente poner en movimiento ${ }^{89}$.

Sin embargo, a principios del verano de 1623 el gran asunto militar para el duque fue el encargo que recibió de preparar los bastimentos, pertrechos y tropas para un gran socorro naval con destino a Cumaná. Una vez comenzó el duque a disponerlo, ni la Junta de Guerra de Indias ni los Consejos habían respondido a sus correos. Todo parece indicar que el temor de Medina Sidonia era que aquellos desajustes respecto a órdenes cuya ejecución implicaba a su autoridad en la zona no se atajasen, perjudicando su crédito como general. Los términos en los que se planteaba el asunto, como exponía a su agente, se resumían en que la misión encomendada no hubiera sido acompañada de los medios y de la jurisdicción precisos para su realización. El desgaste de la autoridad del duque era doble: como jefe militar y reclutador, por cuanto 200 hombres habían quedado embarcados y detenidos dos meses en puerto; además, perjudicaba a su hacienda, ya que los soldados en aquel tiempo apenas habían recibido más socorros que los que el propio duque fue capaz de entregarles de su dinero ${ }^{90}$. En septiembre, con la mediación del secretario Juan Ruiz de Contreras, el agente se mostraba confiado en que lograría que se resarciese al duque de los gastos hechos, valorados en más de 18.000 reales $^{91}$.

Aquella ocasión pareció apropiada a Medina Sidonia, siempre con la ayuda del secretario Anaya, para extender su autoridad en el nombramiento de los cabos de la Armada de la Guarda de la Carrera de Indias. Tras una larga entrevista con Anaya sobre este particular, el agente Vallejo remitió al duque la propuesta del secretario. Según éste, dado que la financiación de una bandera de infantería que se embarcaba en dicha armada y que corría a cargo de la Real Hacienda - y no de la avería, que «no las socorre ni tiene obligación porque está pagando las que navegan conforme a su asiento»-, el duque podía escri-

\footnotetext{
89 ADMS, leg. 3.001, d. 260, carta de 28 de mayo de 1623.

90 ADMS, leg. 3.001, d. 185, carta de 27 de agosto de 1623.

${ }^{91}$ Cantidad que el duque había anticipado sobre una partida que la ciudad de Cádiz debía al rey. ADMS, leg. 3.001, d. 262, carta de 19 de septiembre de 1623.
} 
bir de su mano al rey para que reformase el dicho tercio, poniéndolo bajo sus órdenes e incluyendo la facultad de hacer los nombramientos. Medina Sidonia de nuevo presentaba el aumento de su autoridad como sinónimo de eficacia. En el trasfondo de este asunto figuraba su interés por resolver la rehabilitación en Sevilla de las compañías de milicia, logrando además que se alojasen tropas en el alfoz de la ciudad por órdenes suyas. Medina Sidonia consideraba que se trataba de una «muy buena sazón y ocasión para introducir nuestro intento y deshacer la duda que en él se ha puesto estos años, que no ha servido más que de indulgencia para los sesenta lugares de la tierra de Sevilla y daño para los demás», entre los cuales, no lo olvidemos, se contaban sus estados ${ }^{92}$.

Tres años después Vallejo relató al duque una frustrada entrevista con Olivares, justo después del regreso del rey de la celebración de las Cortes de Aragón y en medio de los preparativos para la entrada del legado pontificio en Madrid. El agente se encontró apenas con el conde-duque el tiempo justo para hacerle entrega de una carta de Medina Sidonia, tras lo cual el valido "pasó al cuarto de Su Majestad, diciéndome que le esperase». Así lo hizo el agente, aunque el siguiente encuentro tardó días en producirse, al parecer porque Olivares se encontraba enfermo. Por la respuesta del duque se deduce que el asunto del que trataba la carta era, una vez más, encontrar apoyo en la Corte para los múltiples asuntos que llevaba entre manos el duque, sobre todo la defensa de Cádiz. Decía que "puedo fiar de la merced que el conde [de Olivares] me debe hacer que, libre de sus achaques, lo dispondrá todo como me lo ofrece». Por otro lado, también el duque estaba por entonces preocupado con una nueva institución que le recortaba facultades jurisdiccionales: el Almirantazgo de Sevilla ${ }^{93}$. Sobre este tema debía también versar la carta entregada al valido, toda vez que el duque advertía: «espero la resolución que se toma con estos ruines del Almirantazgo, puesto que yo la tengo de mudar de estilo con ellos con que creo nos entenderemos mejor».

El duque por entonces también estaba empeñado en lograr que se permitiese a ciertos cargos de la Hacienda Real - aquellos que se ocupaban del suministro de los fondos empleados bajo sus órdenes - tener su sede en Sanlúcar para tenerlos más a la mano en las ocasiones. El pliego en el que Medina Sidonia exponía su petición al Consejo de Estado iba abierto para que Vallejo entendiese al asunto y ayudase a lograrlo, hablando a quien fuese oportuno ${ }^{94}$. El intento de control más estrecho de los oficiales de la hacienda tenía como fundamento la otra gran actividad militar de la que se ocupaba por aquellos años

92 ADMS, leg. 3.001, d. 246, carta de 31 de julio de 1623.

93 El Almirantazgo fue creado el 4 de octubre de 1624. Ver DomíngUEZ OrTIZ, Antonio: «El Almirantazgo de los países septentrionales y la política económica de Felipe IV», en Hispania, (Madrid) 27 (1948); ConCHA, Ignacio de la: «El Almirantazgo de Sevilla», Anuario de Historia del Derecho Español, (Madrid) XIX (1948), pp. 459-525; ElliOTT, Jonh H.: El conde-duque de Olivares. El político en una época de decadencia, Barcelona, 1991 [Yale, 1986], p. 175.

94 ADMS, leg. 3.001, d. 486, cartas de 18 y 31 de mayo de 1626. 
el duque: el cuidado y abastecimiento de los presidios africanos de Larache y Mamora - conquistados unos años atrás bajo el amparo del VII duque. Para entender en su justa medida el significado de estas conquistas, debemos reparar en que su valor estratégico se inscribe en la defensa costera de Andalucía frente a la piratería. Para los duques, ambas plazas representaban una ocupación constante y un medio de ejercer su autoridad muy considerable, además de una puerta abierta a nuevas posibilidades expansivas, militares y comerciales. Más aún, la amplia capacidad decisoria que fueron acumulando de facto en las materias magrebíes les permitió inmiscuirse cada vez más en la política interna marroquí, apoyando a uno u otro rey o interviniendo en las luchas de facciones entre diversos poderes locales. En contrapartida, los presidios eran fuente de problemas, sobre todo en lo que se refiere al abastecimiento. Desde los primeros años de dominio castellano se hizo evidente que el sostenimiento de las plazas con garantías implicaba crear un sistema financiero capaz de abastecerlas de forma constante, toda vez que su supervivencia dependía por entero del suministro enviado desde la península.

La creación ex novo de una estructura de administración permanente para estos presidios se hizo en tiempos del duque don Manuel Alonso, siendo el motivo más constante de solicitud por parte del duque a los Consejos de Madrid y al rey. En un primer momento, las soluciones ofrecidas desde la Corte a las necesidades que se iban presentando fueron parciales e inestables, generándose así retrasos en las mesadas. En las ocasiones más apuradas hubo de ser el duque quien cubriese con su propio dinero las necesidades de los presidios, dando lugar a cierta tirantez entre el duque y el Consejo de Hacienda. También en esta materia la labor del agente era esencial, procurando que las libranzas se acelerasen con procedimientos similares a los usados para los otros negocios, tratando antes que nada con el secretario de Guerra, en quien la acogida siempre era más favorable, para que ayudase en la presión. En 1629, siendo Pedro de Arce secretario de guerra, el duque buscó por medio de su agente, Liébana, que se viese adecuadamente en el Consejo la situación desesperada de aquellas plazas. Más que en las partidas aisladas que se le ofrecieron, el duque tenía por entonces puesta la mira en una solución estable, aprovechando entre otras cosas la presencia de su hermano, el marqués de Fuentes, en el Consejo de Guerra, para que con su «autoridad y cuidado se facilite el satisfacerme a los despachos»95. La propuesta del duque era la asignación de una renta regia fija en Andalucía para el sostenimiento de las plazas, sistema que se completaría con la creación de una proveeduría específica para Larache y Mamora. Para lograr el intento, como recordaba el duque a su agente, había que sacar partido a los momentos

95 El marqués fue un contacto muy importante para el duque sobre todo desde que ocupó plaza de consejero de Guerra. Por eso el duque lo mantuvo «regalado», por ejemplo enviándole un tiro completo de caballos frisones para su coche en 1635, cuyos aderezos incluían unas mantas con las armas del duque. ADMS, leg. 3.063, cartas de 13 y 28 de marzo de 1628 y ADMS, leg. 3.083, carta de 27 de febrero de 1635 . 
en los cuales los avisos de Berbería «causan cuidado, que entonces es cuando más viva ha de estar la diligencia». De nuevo el conde-duque debía ser la referencia de estas instancias, por lo que Medina Sidonia ordenaba a Liébana que se entrevistase con el valido ${ }^{96}$. Meses después, en aquellas condiciones de favor, el duque, ante la imposibilidad manifiesta de la Corona de proveer de lo necesario a los presidios, tuvo que aceptar — según sus palabras en carta a su agente— «la condenación de asistirlas este verano y de aliviar de cuidado a Su Majestad, pero convendrá que saquéis las órdenes muy apretadas y ajustadas para que los generales socorran en ocasiones de sitio con gente y municiones ${ }^{97}$.

Ante la falta de resolución, en 1630 Medina Sidonia remitió a don Juan de Otáñez, veedor en Cádiz, para que representase en la Corte las dificultades tanto de aquella ciudad como de los presidios africanos. En su misión debía estar apoyado y asesorado por el agente, don Gaspar de Liébana, al cual informó el duque de la dramática situación ${ }^{98}$. Por entonces logró el duque un éxito parcial cuando fue nombrado proveedor de los presidios un vasallo suyo con vinculaciones concretas con su hacienda, como vimos: don Fernando de Novela. Sin embargo, solucionada la cuestión del gasto, seguía pendiente el problema de la financiación, porque los asientos firmados entre la Corona y Novela implicaban que las partidas debían ser aprontadas por el proveedor general de Andalucía, Octavio Centurión. Además, aquel logro del duque quedó en papel mojado unos meses después a causa del experimento de la contribución única de la sal, al quedar suprimidos los ramos de rentas asignados para suministro de las plazas. Así pues, mientras el duque defendía su derecho a explotar libres de derechos ciertas cantidades de sal en los tribunales, Novela peleaba porque se le hiciesen ciertas las partidas que se le habían asignado en su asiento con la Corona para hacer frente al abastecimiento de los presidios. Según lamentaba el proveedor, su quiebra amenazaba con impedirle seguir con sus propios negocios. El fracaso del experimento barrió de este modo el éxito que tanto había costado lograr al duque, consistente en poner en alguna medida bajo su control una forma estable de abasto. Tras muchas quejas del duque y de Novela, juntos y por separado, a los Consejos de Hacienda y Guerra, en 1633 pareció encontrarse una solución al problema cuando se barajó la posibilidad de que una parte de los derechos sobre el pescado - que se habían impuesto recientemente en Andalucía para el mantenimiento y fortificación de Cádiz — se destinase a las plazas africanas ${ }^{99}$. Medina Sidonia volvió a encargar a su agente que continuase tratando con el conde-duque la fijación definitiva de esta partida, recurriendo a la ayuda de su hermano, el Patriarca, y de su hijo, el conde de Niebla, ambos entonces en Madrid ${ }^{100}$.

96 ADMS, leg. 3.063, carta de 29 de julio de 1629.

${ }_{97}$ ADMS, leg. 3.063, carta de 24 de marzo de 1630.

98 ADMS, leg. 3.063, carta de 25 de junio de 1630.

99 Mencionaba el duque la materia en carta a su agente de 4 de septiembre de 1633 . ADMS, leg. 3.063.

100 ADMS, leg. 3.063, carta de 20 de noviembre de 1633. 
Fuera porque el derecho del pescado resultase una renta incierta o porque su cobro quedase impedido por alguna disputa en los tribunales, el hecho es que en 1635 los problemas de la defensa de Cádiz volvieron a plantearse con urgencia. En este caso el intento del duque fue renovar la institución de la milicia — cuya creación databa de $1596^{101}$ — , completándola con el viejo proyecto ducal de crear una caballería concejil, heredera de aquella formada por los cuantiosos. El doble proyecto aspiraba también a convertir en «dueño a cada señor de por sí de lo que toca a sus estados» en materia de estas milicias, alistando y nombrando los mandos. Según el duque su propuesta iba desnuda de ambición, sólo motivada por el deseo de evitar litigios entre los señores. Medina Sidonia optó entonces por remitir de nuevo a un ministro regio a la Corte a solicitar estas materias, esta vez el veedor don Leonardo de Soria Camargo. En un principio, sus gestiones parecieron dar buenos frutos gracias a la asistencia en los negocios de don Fernando Ruiz de Contreras. De este secretario el duque decía era «bonísima persona [...] y aunque tan ocupado, si en su tiempo no ponemos en buen estado la ejecución de los arbitrios de la caballería e infantería, dudo que se consiga nunca»102. Sin embargo, pronto surgieron inconvenientes. Así, con respecto a la caballería, el duque lamentó que la discusión en Cortes se hubiese saldado con el rechazo del proyecto por parte del Reino, dando por supuesto el duque que tal cosa se debió a que el proyecto no había sido expuesto en los términos adecuados, en el sentido de que la caballería debía formarse no por vía de cuantía — que equivalía a decir por apremio y pecho-, sino con nombre de voluntaria — con invitación por medio de premios y honras que doblasen las del resto de vecinos ${ }^{103}$. En palabras del duque, se trataba de un intento "por el servicio del rey y por el bien universal de estos reinos»104. Por lo demás, el duque lamentaba que los informes que recibía del veedor Leonardo de Soria fueran «diferentísimos» de los que recibía de su nuevo agente, don Juan de Olivares, al que ordenaba tratar con el veedor para unificar criterios en materia tan importante ${ }^{105}$.

Meses antes de su muerte, el gran empeño del duque fue lograr que se proveyese la gobernación de Cádiz en la persona de su hermano, el marqués de Fuentes, "para que con sus experiencias ayudase y aliviase mi cuidado». Tanto le importaba el asunto que estimaba que si el conde-duque le hiciese esta merced, como parecía dispuesto, sería la mayor que podría hacer por él y por el servicio del rey, aunque no dejó de lamentar Medina Sidonia «que mi solicitud tan anticipada y de todos los que ahí tengo no hayamos podido arrancar resolución fija en lo de los arbitrios de la caballería e infantería y en la provisión de

\footnotetext{
101 ADMS, leg. 2.402, carta de 7 de octubre de 1596.

102 ADMS, leg. 3.083, carta de 9 de septiembre de 1635.

103 ADMS, leg. 3.083, carta de 30 de septiembre de 1635.

104 ADMS, leg. 3.083, carta de 28 de octubre de 1635.

105 ADMS, leg. 3.083, carta de 6 de enero de 1636.
} 
las armas ni entretenidos» ${ }^{106}$. De esta gráfica manera reflejaba el duque la decepción que le producía la comprobación de que los proyectos de reforma interior de su pariente hubiesen sido desplazados gradualmente por las urgencias de la guerra en Europa.

\section{EN EL ALCÁZAR DE MADRID: LA VOZ DEL DUQUe Y LOS OÍDOS DEL REY}

El círculo más restringido de decisión en torno al rey en el siglo XVII estaba sin duda dominado por el polifacético fenómeno del valimiento ${ }^{107}$. Llegar a influir sobre este mecanismo de control del acceso al monarca que era el valido requería de cauces de comunicación algo diversos a los que hemos visto hasta ahora. Haciendo un rápido esquema, podemos presentar este último nivel de relación como un equilibrio de expectativas de acción y respuesta mutuas. En primer lugar, para un grande alcanzar el apoyo del valido en sus negocios significaba la aceptación en términos generales de la orientación del gobierno regio plasmado en la elección de un valido y traducida en la toma de decisiones concretas. En segundo lugar y en sentido inverso, para ese mismo grande obtener una actitud proclive del valido se traducía en el respeto y defensa de sus privilegios. A este nivel, el equilibrio de la contraprestación se hacía mucho más amplio y genérico. Para ambos poderes, situados en los extremos de este canal de comunicación, aunque asimétricos en el balance global y en la naturaleza de su poder, contar con el apoyo del otro suponía una ventaja sustancial para el logro de sus fines. Ahora bien, en las inmediaciones de esa intimidad decisoria del monarca se extendía la pléyade de grandes, títulos y señores que componían eso que se ha venido en denominar nobleza de Corte, a la que debemos agregar algunos grandes ministros de los llamados de toga ${ }^{108}$. Algunos de ellos ocupaban cargos palatinos, otros en los Consejos reales y algunos más eran pretendientes o su paso por Madrid era temporal. En todo caso, constituían la materia de la que surgía y sobre la que se tejía la política cortesana, dominada por el afán de alcanzar una posición desde la que tratar de hacer sentir la propia influencia en las cercanías del monarca ${ }^{109}$. Sobre este tejido el duque ausente bus-

106 ADMS, leg. 3.083, carta de 2 de marzo de 1636.

107 El fenómeno europeo del valimiento sigue siendo objeto de atención por los especialistas desde hace ya varias décadas. Baste recordar dos títulos colectivos recientes: BrockLISS, L. y ElLiOtT, J.H. (dirs): El mundo de los validos, Madrid, 1999 [Yale, 1999]; y EsCudero, J.A (coord.), Los validos, Madrid, 2004.

${ }^{108}$ La Corte ha sido objeto de numerosas publicaciones en los últimos años —una visión de conjunto bastante actualizada en VÁzQuez GeSTAL, P.: El espacio del poder. La Corte en la historiografía modernista española y europea, Valladolid, 2005- y de congresos monográficos -BRAVO LOZANO, J. (ed.): Espacios de poder..., op.cit.

109 Álvarez-Ossorio AlvariÑo, Antonio: «El Cortesano Discreto: itinerario de ciencia aúlica (ss. XVI-XVII)», en Historia Social, 28 (1997), pp. 73-94. 
caba mantener una presencia a través de su agencia como recuerdo de su poder y bandera de sus fines e intereses.

Un apoyo de indudable utilidad para el duque y sus agentes lo constituía la propia familia en sentido amplio. Los lazos más fuertes de aquellos años de los Medina Sidonia con esa nobleza cortesana eran los establecidos con los duques de Pastrana, relación inaugurada por la vieja alianza matrimonial del VII duque y la hija de los príncipes de Éboli, la duquesa doña Ana de Silva y Mendoza, en la década de 1560. En la época del VIII duque ambas Casas estaban doblemente emparentadas, siendo por aquel entonces duquesa de Pastrana una hermana del duque de Medina Sidonia, doña Leonor de Guzmán. La escenificación de aquellas alianzas, o por mejor decir, el hilo que mantenía viva aquella buena correspondencia, era el intercambio de favores y regalos relacionados con la cetrería y la equitación. Por otro lado, la corte ducal de Pastrana, relativamente próxima a Madrid, fue en muchas ocasiones refugio para los vástagos de la Casa de Medina Sidonia que pretendían algo en la Corte o que tenían cargo en ella, por lo que los viajes y recados de los agentes a la ciudad alcarreña fueron muy frecuentes ${ }^{110}$. Estas finezas entre iguales tenían su traducción en todo un despliegue de atenciones cortesanas que incluían lutos y pésames, recibimientos por parte del agente — salida del agente a recibir a un pariente a varias leguas de Madrid en nombre del duque — o felicitaciones por los buenos sucesos. Por su parte, Pastrana, en el desempeño de sus cometidos — como fue su embajada en Roma - trataba de favorecer las necesidades de Medina Sidonia ${ }^{111}$.

La labor de representación del agente del duque ante la propia familia se extendía obviamente a otros títulos y grandes de Castilla, aunque la frecuencia y grado de fineza difieran. En la inquieta Corte de Madrid de los años posteriores a la caída de Lerma en octubre de 1618, descrita por la historiografía como un largo período de incertidumbre en el poder, en el que ningún privado o camarilla alcanzó a ocupar la posición del antiguo valido ${ }^{112}$, Medina Sidonia multiplicó sus contactos cortesanos por medio de una serie de cartas, dirigidas a conspicuos cortesanos, que el agente en Madrid fue repartiendo en entrevistas personales. Señalemos a modo de ejemplo que en una carta del 14 de abril de 1620 de Bernabé de Robles a su señor, con respuesta del duque al margen, se cuentan, entre otros varios señores a los que el agente había visitado en nombre de don Manuel Alonso, ocho grandes y títulos, a algunos de los cuales aparentemente sólo se daban muestras de cortesía en forma de enhorabuenas o pésames ${ }^{113}$.

${ }^{110}$ A modo de ejemplo, en 1618 don Jerónimo de Escobedo recibió el encargo de financiar la visita que don Bernabé de Robles, enviado especial del duque a Madrid, iba a hacer a don Miguel de Guzmán, estante por entonces en Pastrana. ADMS, leg. 2.949, carta de 11 de octubre de 1618.

111 Varios ejemplos de estas finezas en ADMS, leg. 3.001, d. 481 y 492, 8 de julio y 29 de marzo de 1626; ADMS, leg. 3.063, 5 de enero de 1629; y ADMS, leg. 3.083, 30 de septiembre de 1635.

112 Antonio Feros habla abiertamente de la «inhabilidad» de Uceda y Aliaga para hacerse con las riendas del poder. El duque de Lerma..., p. 442.

113 Se trata del conde de Saldaña — hijo segundo del duque de Lerma—, de los marqueses de 
Conocemos algo más de las circunstancias y contenido de una nueva ronda epistolar a la que procedió Medina Sidonia al inicio del reinado de Felipe IV. Por entonces, los aires de revancha contra los responsables de la política del anterior reinado amenazaban con salpicar a toda la parentela del antiguo valido. Sin embargo, la relación de don Manuel Alonso con su suegro, el entonces cardenalduque de Lerma, que a comienzos del reinado de Felipe IV hacía varios años que había caído de su preeminente posición, continuó siendo intensa, aunque compleja. Sabemos que el duque recurrió a enviados especiales para tratar diversas materias con el otrora privado y su familia. Don Bernabé de Robles - que por entonces estaba en la Corte ejerciendo de agente especial del duque- fue encargado de distribuir correos urgentes a varios personajes cercanos a Lerma -un secretario, el doctor Juan González Centeno, y un maestresala, Luis González del Castillo- aunque no nos conste el contenido de las misivas. Al mismo tiempo, el propio Medina Sidonia remitía desde Sanlúcar a otro emisario extraordinario - don Cipriano de la Cueva - a Valladolid a tratar a boca con su suegro ${ }^{114}$. De este modo, en apariencia, los nuevos tiempos no habían llevado al duque a mover su fidelidad a Lerma y su parentela, a los que el duque no dejó de favorecer. Esta actitud debe ser entendida como un intento de demostración de fortaleza política, aunque bien es cierto que algunas de las acciones más significadas de favor del duque tuvieron como beneficiarios a aquellos miembros de la parentela de Lerma mejor situados para sobrevivir políticamente a los cambios que para entonces ya eran evidentes ${ }^{115}$.

De hecho, cuando el espinoso asunto de la persecución en los tribunales a los antiguos validos y sus hechuras - que aparece aludido en nuestra correspondencia como «las cosas del cardenal-duque»— fue tomando cuerpo, parece que la suerte de su suegro fue la única que preocupó a Medina Sidonia. Lerma fue formalmente acusado por don Juan Chumacero de haber acaparado «exorbitantes mercedes», dando lugar a una causa que no se llegó a sentenciar firme y definitivamente en vida del antiguo valido. A lo que sí se procedió fue al embargo de sus bienes. Como señala Benigno, recogiendo los argumentos de la defensa del cardenal-duque, la acusación del fiscal lo que en el fondo ponía en cuestión era la autoridad de Felipe III ${ }^{116}$. Sin embargo, cuando en 1623 la causa comenzaba a perder fuerza, fue descubierta una carta de Lerma dirigida a

Camarasa —primo de Olivares, según BENIGNO, Francesco: La sombra del rey. Validos y lucha política en la España del siglo XVII, Madrid, 1994 [Yale, 1992], p. 119-, Velada, Astorga, Villanueva de Barcarrota y de los duques de Segorbe, Béjar y Alba. ADMS, leg. 2.949, carta de 14 de abril de 1620.

114 ADMS, leg. 2.949, cartas de 6 y 7 de mayo de 1619.

115 Entre ellos, don Bernardo de Sandoval y Rojas, quien recibió tras su visita a Sanlúcar el regalo de dos esclavos moros - aunque al fin tuvo que devolverlos por cuestiones de diplomaciacapturados mientras fue huésped del duque. ADMS, leg. 3.001, d. 183 y 185, cartas de 26 y 27 de agosto de 1623.

116 Benigno señala que la causa contra Uceda fue criminal, lo que implicaba un enjuiciamiento del sistema de gobierno. BENIGNO: La sombra del rey..., 123-128. 
don Pedro de Arellano, en la que el antiguo valido expresaba su deseo de acudir a besar la mano al rey, deseo tan ardiente como para plantearse hacerlo sin pedir licencia, porque "puesto una vez aquí [en Madrid, el rey] no le había de echar». El momento era particularmente oportuno para reabrir el proceso de Lerma, ya que el Príncipe de Gales — entonces en Madrid - había preguntado a Felipe IV por el paradero de Lerma porque «holgaría verle», produciendo no poco revuelo en los mentideros. La coincidencia de ambos elementos causaron tanta preocupación a Olivares y al rey que, según se decía, se andaban buscando de nuevo culpas al viejo valido ${ }^{117}$. El agente del duque en Madrid, Vallejo, agregó en una carta dirigida a su señor que

«aunque culpas Vuestra Excelencia no las puede haber, todavía estaré a la mira para lo que se ofreciere, siendo de la memoria de Vuestra Excelencia»118.

¿Cuál podía ser esa culpa que, no teniéndola, era temida por el agente? Para comprender el alcance de esta alusión debemos remontarnos a los primeros meses del reinado de Felipe III, cuando el matrimonio entre don Manuel Alonso, a la sazón conde de Niebla, y la hija segunda del por entonces marqués de Denia, culminó un proceso de acercamiento político muy prometedor entre el nuevo valido y el VII duque don Alonso. Las extraordinarias mercedes de que fue objeto la Casa de Medina Sidonia iban desde el pago de contado de la dote de la hija de Lerma — fijada en 100.000 ducados pagados por el rey- a los cargos que fueron concedidos al duque y a su primogénito ${ }^{119}$. Tampoco está de más recordar que, según el nuncio apostólico en Madrid, doña Juana de Sandoval, antes de casar con el heredero de Medina Sidonia, había estado desposada con el marqués del Carpio, quien después casó con la hermana de Olivares $^{120}$. En todo caso, el VIII duque tenía un complicado escenario político y familiar por delante que sólo la muerte fue despejando.

Al morir la duquesa de Medina Sidonia, doña Juana de Sandoval y Rojas, en 1624, el duque envió sus condolencias a varios miembros del clan familiar de su mujer, constándonos las dirigidas a la condesa de Lemos, al conde de Saldaña y al señor don Francisco de Castro ${ }^{121}$. A la muerte de Uceda, en diciembre del mismo año, Medina Sidonia remitió a Bernabé de Robles a dar el pésame a Lerma, añadiendo unas instrucciones en las que el duque hacía toda

117 Una opinión en contrario en Antonio Feros, según la cual la causa contra Lerma no prosiguió más allá del embargo porque tanto Olivares como Felipe IV se habían «olvidado» de él. En El duque de Lerma..., 463.

118 ADMS, leg. 3.001, d. 246, carta de 31 de julio de 1623.

119 Don Alonso fue nombrado consejero de Estado y luego también de Guerra, mientras su hijo, don Manuel Alonso, fue agraciado con el cargo de montero mayor y más tarde con el de Capitán General de las Galeras de España.

120 Archivio Segreto Vaticano, Segreteria di Stato, Spagna (ASV, Segr. Stato, Spagna), leg. 49, 381v-382r, carta del nuncio Gaetano al cardenal Aldobrandini, sin fecha, de 1598.

121 ADMS, leg. 3.001, d. 290, carta de 14 de agosto de 1624. 
una protesta de fidelidad a su suegro, ponderando lo mucho que había tratado de hacer por él en su desgracia, sin ahorrar trabajo, salud ni hacienda, pero que al cabo en nada había quedado tanto esfuerzo. Debía transmitirle su consuelo y el ofrecimiento de sus servicios en lo que ahora pudiese estarle bien. Hablaba en términos de reconocimiento de la merced que debía al antiguo valido, sobre todo «con haberme dado tal compañía» — su difunta esposa. Don Manuel Alonso remitía como presente una reliquia que doña Juana había dejado a su padre en el testamento, a lo que él mismo agregaba un rosario de coral con diamantes. Por otra parte, Robles debía recordar a Lerma que el testamento de la duquesa lo había interpretado el duque con mayor generosidad en «cantidad de misas y sufragios». Aún más, Medina Sidonia había olvidado ciertas mercedes hechas por Su Majestad para sus propios hijos —incluido el conde de Niebla - para no embarazar la parte de la herencia de la duquesa que tocaba a Lerma ${ }^{122}$.

En todo caso, el 18 mayo de 1625 murió el cardenal-duque, despejando en buena medida el panorama político a Medina Sidonia, sobre todo teniendo en cuenta que por entonces el acercamiento al nuevo valido era notable. De hecho, la insistencia de don Manuel Alonso en ponderar a Lerma las muchas vías por las que le había servido en su desgracia no dejan de poner en evidencia por omisión el apoyo político que acaso no había prestado al suegro. Por su parte, el agente se refirió brevemente a los grandes lutos que se habían hecho en Madrid por el viejo valido, tales que «no se puede encarecer» ${ }^{123}$.

Desde luego, el ascenso al trono de Felipe IV había obligado, fuese cual fuese la voluntad de Medina Sidonia respecto a su suegro, a reorganizar la estrategia de su presencia en la Corte para garantizar su posición en Andalucía. Al año de la muerte de Felipe III, Medina Sidonia quiso mostrar su buena voluntad al joven Felipe IV por medio de un costoso regalo cargado de valor simbólico. Se trató de tres caballos de su famosa cuadra, junto con varias ballestas y una escopeta de lujosos taraceados, sólo por cuyos aderezos pagó el agente en Madrid 1.300 ducados. Las instrucciones del duque para la presentación del regalo fueron minuciosas, quedando encargado el agente de disponerlo todo con mucho secreto para acentuar el efecto de sorpresa ${ }^{124}$. El simbolismo de la caza como ejercicio virtuoso de preparación para la guerra era claro en este presente ${ }^{125}$, como lo fue en algunos otros en los que el duque se prodigó entre la parentela de Olivares ${ }^{126}$.

122 ADMS, leg. 3.001, d. 302, carta de21 de diciembre de 1624.

123 ADMS, leg. 3.001, d. 453, carta de 22 de mayo de 1625.

${ }^{124}$ Los trajes de los mozos, las cajas de las armas y los caballos debían ir cubiertos de terciopelo verde, bordado de pasamanerías de oro y seda. Don Juan de Castro a Medina Sidonia, ADMS, leg. 3.001, d. 71, 104 y 106, 12 de agosto y 25 de octubre de 1622 .

125 No en balde un autor hablaba en 1634 de la caza como «academia de Hércules». Citado en VALLADARES, Rafael: «El arte de la guerra y la imagen del rey. Siglos XVI-XVIII», en La guerra en la Historia, Salamanca (1997), pp. 163-189, p. 184.

${ }^{126}$ Como fue el caso en 1623 del joven sobrino de Olivares, don Luis de Haro, a quien el duque regaló ciertos «aderezos de monte». ADMS, leg. 3.001, d. 221, carta de 1 de octubre de 1623. 
Desde luego había que contar con la figura ascendente de Olivares ${ }^{127}$. Hacia 1623, coincidiendo con la consolidación en la Corte de la privanza del conde, el duque nombró a un nuevo agente único en Madrid, don Pedro de Vallejo Cabañas, quien había solicitado el cargo y contaba con la plena confianza del duque. El consejo ducal destacó de Vallejo su fidelidad a la Casa de Medina Sidonia, a la que ya llevaba algún tiempo sirviendo. A la hora de instruirle en su nueva ocupación, el duque le hizo notar la cortedad de papeles que generaba la agencia, por lo que le advertía que consultase sus dudas con Pedro de Robles, que en adelante ejercería de solicitador del duque en Madrid. No obstante, Medina Sidonia daba por seguro que en pocos días Vallejo habría entendido la política de la Casa en los diversos asuntos que se llevaban en la Corte, confiando en su maña para tratar con «Su Majestad [y] con los parientes y amigos». En todo caso, Vallejo debía acudir antes a Sanlúcar para ser instruido a boca. Tanto esperaba Medina Sidonia de Vallejo que en la posdata escribió que «ni vos podéis estar sin mi ni yo sin vos» ${ }^{128}$.

Ya en Madrid, Vallejo inició la preceptiva ronda de visitas a diversos personajes cortesanos. Sin embargo, la suya fue una serie de visitas algo más extensa que las anteriores y dictada por la misión del agente de sondear el estado de ánimo o inclinación de la Corte en general hacia el duque. Vallejo fue dando cuenta más o menos por extenso «de lo que se ofrece» en tres cartas — de las que hemos podido localizar dos- en las que describía sus visitas, en los márgenes de las cuales el duque anotó su parecer. La nómina de los visitados es, pese a la carencia de la primera carta, impresionante. Cabe suponer que algunos de los contactos familiares referidos en la misiva perdida fuesen aquellos que con más cuidado trataba el duque en aquellos años, muy especialmente la marquesa viuda del Carpio - hermana de Olivares_ y su hijo don Luis Méndez de Haro ${ }^{129}$. Acaso se encontrasen también referencias a la familia de los Borja, contacto familiar relevante de los Medina Sidonia en todo el siglo XVII. Lo cierto es que el duque aprobó el modo y los resultados de la gestión de su agente, insistiendo en que mantuviese contentos a los más favorables y que procurase tener en cada Consejo a alguien «grato», obligado en algún modo, con quien mantendría don Manuel Alonso su correspondencia. Para ello debía el agente tratarlos «sin confianzas», como sabría sin duda hacer Vallejo con su buena maña.

127 ELLIOTT: El conde-duque..., pp. 147 y siguientes.

128 Aún antes de salir de Andalucía, Vallejo se volvió a entrevistar con el duque y su hijo, el conde de Niebla, en Villamanrrique, al parecer para tratar de la boda del conde con su tía paterna, negocio que se llevaba con mucho secreto. ADMS, leg. 3.001, d. 224 y 289, cartas de 13 de marzo y 21 de abril de 1623.

129 A ambos trató Medina Sidonia de favorecer por medio del apoyo a sus recomendados en Andalucía. Notable fue el caso de un obispo de Cádiz, protegido de los marqueses del Carpio para favorecer al cual había dado orden el duque a todas las justicias de sus estados incluidas en tal jurisdicción episcopal de rendirle toda la pleitesía exigida, seguramente porque el prelado estuviese en entredicho. ADMS, leg. 3.001, d. 263, carta de 11 de noviembre de 1623. 
De muchos de los visitados el agente sólo comentaba que recibieron la carta con agrado y que mostraron su buena disposición a servir al duque cuando se presentasen ocasiones ${ }^{130}$. En otros casos el agente se explayó algo más. Así, del duque de Cea — sobrino de Medina Sidonia - y del marqués de Toral, refirió sus cualidades de buenos caballeros y su disposición muy favorable al duque. Toral decía estar dispuesto a guardar la tradición de su padre, muy inclinado al duque don Alonso, razón por la cual Medina Sidonia destacó su confianza en él. Otro título que salía bien parado en la consideración del duque era el marqués de la Hinojosa, en justa concordancia con la excelente acogida que su carta había tenido en él. Por el contrario, del presidente de Hacienda decía Vallejo que, si bien había reconocido estar dispuesto a servir al duque en lo que fuese preciso, había estado algo «seco». Más preocupó la actitud del marqués de Alemquer — tío de don Manuel Alonso-, quien, tras esquivar varios días al agente, al fin lo recibió con cierta frialdad, por lo que Vallejo sólo le dejó entrever una parte de lo que debía decirle. El duque sugería a su agente que atendiese estos «desvíos» del portugués, dada la «obligación en que le puse en los tiempos pasados, buscándole cuando otros se le apartaban, aventurando la gracia del duque [de Lerma] por esto y lo que defendía sus causas, que será bien acordárselo» ${ }^{131}$.

La entrevista con el príncipe de Esquilache, del que también decía el agente que era «muy servidor de Vuestra Excelencia», tuvo así mismo un tratamiento más profundo por parte de Vallejo. Refería que el príncipe había ofrecido una pieza de su palacio al duque para cuando tuviese a bien acudir a Madrid, oferta que declinó cortésmente el agente, diciendo que no lo creía inminente, dado que no tenía el duque orden del rey de hacerlo y que, aún más, era de mayor utilidad su asistencia en la guarda de la costa que en otra labor alguna. Estas y otras razones, decía Vallejo, habían obligado a Esquilache

«a decir que de cualquier manera hacía bien Vuestra Excelencia en estarse en su casa y grandeza y que todos eran escuderos de Vuestra Excelencia y los más que hablan en la materia dicen que hubiera sido desairada cosa ver a Vuestra Excelencia en ocasión tan molesta»132.

\footnotetext{
${ }^{130}$ Figuran, aparte de los más cercanos familiares (la Casa de Pastrana, el Patriarca de las Indias y los hermanos del duque), el Inquisidor General, los duques del Infantado, Cea y Maqueda, marqueses de Toral, Malpica y la Hinojosa, el conde de Chinchón, el príncipe de Esquilache, don Diego de Ibarra, don Diego Brochero, don Gonzalo Pérez de Valenzuela, don Juan Chaves, el licenciado Solórzano, don Rodrigo de Escobar, don Pedro de Toledo y Juan Martínez de Escobar.

${ }_{131}$ Esta tirantez parece que no duró mucho, toda vez que a la muerte del marqués el duque dijo sentirse «muy tierno» por la pena, encomendando al agente que saliese a recibir al duque de Híjar, su primo, a una jornada de la Corte para darle el pésame por la muerte de su padre. Debía a su vez representarle cómo había tenido orden de acompañar el féretro pero que no lo hizo por coincidir con la llegada del conde de Niebla a Madrid. ADMS, leg. 3.063, carta 25 de junio de 1630.

132 ADMS, leg. 3.001, cartas de Vallejo de 8 y 10 de mayo y respuestas del duque de 27 de mayo de 1623.
} 
No tenemos seguridad sobre cuál era esa ocasión que hubiese supuesto un desaire al duque, pero parece bastante probable que se tratase de la apertura del proceso al cardenal-duque de Lerma. En definitiva, lo más significativo desde nuestra perspectiva de estudio es la oportunidad en la que Medina Sidonia sondeó sus apoyos, unas semanas después de que con la llegada del príncipe de Gales a pretender la mano de la infanta María, se hubiese consolidado la imagen de Olivares como ministro principal de Felipe IV. El valimiento de este pariente Guzmán — grande desde hacía poco más de un año-, no lo olvidemos, significaba por entonces el apoyo abierto a algunos planes de reforma interior con los que casaban perfectamente los intereses del duque, muy especialmente los referentes a la reactivación comercial. Si a esto le sumamos que en las negociaciones del matrimonio inglés estuvo muy presente el comercio, podemos entender el esfuerzo del duque por hacer recordar su voz en la Corte ${ }^{133}$.

Sobre el gran acontecimiento cortesano que eran los festejos en honor del príncipe Carlos y el duque de Buckingham, Vallejo fue desgranando detalles, algunos de los cuales se asemejaban a las relaciones de corte. Así refirió el agente haber asistido a una comida en palacio, dando fe de que el príncipe de Gales era servido del mismo modo que se hacía con Su Majestad. No eludía las cuestiones políticas del viaje del heredero inglés, refiriendo lo que sabía de las deliberaciones de la Junta que trataba el matrimonio de la infanta. Describía el asunto como confuso, dado que - así lo calificaba él- el de Gales era «gran hereje, con que asegura ser dueño de aquel reino. Da a entender que está muy aficionado de la infanta, anda vestido con poco lucimiento y [en] los criados que trae gástase mucho con ellos». Las consecuencias de tanto festejo, según Vallejo, eran que la Corte vivía más ocupada del ocio que del gobierno, lo cual estaba dificultando su labor de buscar la resolución de algunos asuntos urgentes ${ }^{134}$.

La distancia no fue excusa suficiente para el duque para mantenerse al margen de aquel despliegue de lujo, sino más bien una oportunidad de deslumbrar a la Corte en su propio terreno. Unas semanas antes de la salida del príncipe de Gales y Buckingham de Madrid, cuando aún parecía factible el matrimonio con la infanta ${ }^{135}$, Medina Sidonia remitió al heredero inglés un «grandioso» presente — valorado en los mentideros de Corte en 100.000 ducados- consistente en 21 caballos escogidos en sus cuadras y en toda Andalucía, lujosamente enjaezados y acompañados de un esclavo cada uno. La entrega se hizo mediante una procesión que recorrió las calles de Madrid con gran acompañamiento de música y lacayos, tomando parte así también el duque en los

133 ElLiotT: El conde-duque..., p. 67 y pp. 214-223.

${ }^{134}$ En concreto citaba al nuevo presidente del Consejo de Hacienda, quien siendo abordado de parte del duque sobre la necesidad de proveer fondos para reforzar la defensa de Cádiz, había respondido que eran muchos los frentes a los que había que acudir. Por esa razón, Vallejo acudió al conde-duque, aunque los muchos asuntos que trataba le impedían atenderle con presteza. ADMS, leg. 3.001, d. 246, carta de 31 de julio de 1623 .

135 RewOrTH, G., El príncipe y la infanta. Una boda real frustrada, Madrid, 2004. 
festejos públicos ${ }^{136}$. No por casualidad Olivares se ocupó de la supervisión general de la procesión en tanto que caballerizo mayor de Su Majestad — cargo que desempeñaba desde diciembre de $1622^{137}$. De hecho, tanto la naturaleza como la ocasión del regalo estaban cuidadosamente escogidos para otorgar al presente su doble significado político. Por una parte, una vez consolidada su preeminente posición, parecía llegado el momento de escenificar de modo ostensible el apoyo de Medina Sidonia al conde de Olivares. Por otra, si de comercio con Inglaterra se hablaba, no estaba de más que el duque demostrase visualmente su poderío. Además, el agasajo al regio invitado era una forma de servicio al rey en su condición de espléndido anfitrión.

Medina Sidonia quedó plenamente satisfecho de la demostración, aunque en cambio algo dolido con su hermano, don Juan de Guzmán, por no haberse tomado la molestia de publicarlo para que corriese y perdurase la fama, porque entendía el duque que era su obligación como miembro de la Casa, "pues no ha sido tan poco considerable [el regalo] que no merezca llegar a noticia de todos y dejar de ella [la demostración] memoria en esta Casa». Por eso, ordenó a Vallejo que se entregase un borrador que narrase lo esencial de la procesión al conocido cronista de corte Andrés de Mendoza para que redactase un texto para su publicación. Tanta importancia daba el duque al asunto que juzgó "podréis desocuparos de los demás negocios para asegurar el acierto de éste». También consideraba que aquel recuerdo debía correr en verso, de lo cual se debía encargar Francisco López de Zárate, procurando el agente que no se contradijesen ambas descripciones. En posdata el duque señalaba que había que resaltar la buena acogida que tuvo en Su Majestad ${ }^{138}$.

Vallejo, por su parte, excusó indirectamente a don Juan de Guzmán de la desatención de no haberlo hecho publicar, diciendo que el asombro había sido tan general en Madrid que hablar directamente de aquel presente con otros grandes y señores era hacerles un agravio comparativo. Aún regaló Vallejo un poco más los oídos de su señor al referirle que

«soy testigo de la circunstancia de un curioso que dijo que este regalo pareció que lo hacía el rey de la Andalucía al de Castilla por feudo y reconocimiento a un amigo suyo y sé también que alguno de los cronistas de Su Majestad, escribiendo

${ }^{136}$ El agente en Madrid se ocupó de todas las cuestiones técnicas de preparación y mantenimiento, dando cuenta a su señor de lo efectuado. Ver, sobre todo, la carta de 1 de agosto de 1623 en la que mostró su impaciencia por la espera de los esclavos para hacer la entrega ceremonial. ADMS, leg. 3.001, d. 247.

137 ElLIOTT: El conde-duque..., p. 67.

138 ADMS, leg. 3.001, d. 240, carta de 10 de septiembre de 1623. López de Zárate ya había sido beneficiario de la generosidad ducal por haber dedicado al duque su primer libro de poesía. Al parecer, don Manuel Alonso le regaló una corona de oro por cada verso del libro [según recoge Rodríguez Marín, Francisco: Pedro Espinosa. Estudio biográfico, bibliográfico y crítico, Madrid, 1907, pp. 181-182]. Al fin no se escribió ninguna de aquellas dos versiones —al menos no hemos podido localizarlas en ningún catálogo bibliográfico. 
la venida del príncipe de Gales y la asistencia que hizo en esta Corte, entre otras cosas que refieren, es el presente de los caballos con grandes ponderaciones».

Aseguraba que habría duradera memoria de la magnificencia de la «más lucida, autorizada y grandiosa y más celebrada [ocasión] que jamás se ha visto y, cuando Vuestra Excelencia haya quedado con algún empeño, lo debe tener por muy bien empleado». No obstante, el duque sostenía en su respuesta que quería verlo por escrito, porque la memoria era «flaca», no queriendo se perdiese la de una ocasión de tanto lucimiento para su Casa, que había servido así a Su Majestad por haber sabido de la falta de caballos que tenía en sus caballerizas $^{139}$. Seguramente el cronista al que aludía Vallejo fuese León Pinelo, que en efecto hizo una descripción de la comitiva, aunque el encargado de ensalzar con más detalle la ocasión fue don Pedro Espinosa, cronista a sueldo de la Casa ${ }^{140}$.

Aún tuvo el duque una nueva ocasión de deslumbrar y agasajar a la Corte en la célebre jornada de Felipe IV y Olivares a Andalucía, uno de cuyos motivos esenciales no declarados era poner al rey en contacto con el estado del comercio americano $^{141}$. En palabras de Espinosa, «halló la Corte a la Corte, y seis mil personas todas sus delicias a su albedrío» ${ }^{142}$. Aquella demostración, por medio de la cual Medina Sidonia deslumbró a la Corte en una exhibición de opulencia sin parangón, fue la escenificación de una proximidad entre ambas cortes bastante notable. Como compensación por aquel esfuerzo - que no dejaba de ser una forma de servicio- Felipe IV nombró a Medina Sidonia consejero de Estado, tomándosele juramento en una reunión del Consejo habida en el palacio ducal ${ }^{143}$. Las peculiares circunstancias de aquella reunión, celebrada bajo la hospitalidad del duque en el centro de su poder, dieron un especial valor simbólico al nombramiento, que daba entrada a la opinión del duque en un foro tan importante como aquél. En cierto modo el palacio mismo quedaba sancionado como sede del Consejo. A ésta se sumaron otras mercedes nada despreciables para los hermanos del duque ${ }^{144}$.

El clima de entendimiento de estas demostraciones se puso a prueba muy poco después. La ruptura de las negociaciones para el matrimonio de la infanta

139 ADMS, leg. 3.001, d. 262, carta de 19 de septiembre de 1623.

140 Quien lo incorporó al «Elogio al retrato del duque de Medina Sidonia» [publicado en Málaga en 1625]. En RodríGuez Marín: Pedro Espinosa...; la versión de Pinelo en Jover, J.M (dir), La España de Felipe IV. El gobierno de la Monarquía, la crisis de 1640 y el fracaso de la hegemonía europea, Historia de España de Menéndez Pidal, vol. 25/1, 691; también citado por BOUZA, F., Locos enanos y bombres de placer en la Corte de los Austrias: oficio de burlas, Madrid, 1991, 140.

${ }_{141}$ ELLIOTT: El conde-duque..., pp. 168 y siguientes.

142 «Panegírico al duque de Medina Sidonia», publicado en RodríGuez Marín: Pedro Espinosa..., p. 344.

143 «Bosque de Doñana a la presencia de Felipo IV», publicado en RodríGueZ Marín: Pedro Espinosa..., p. 396.

${ }_{144}$ Así, meses después, en una entrevista personal de Vallejo con Olivares, el agente recordó al valido lo que preocupaba al duque acomodar a su hermano don Alonso Pérez de Guzmán, quien al fin fue nombrado Patriarca de las Indias. ADMS, leg. 3.001, d. 476, carta de 6 de septiembre de 1626. 
con el ya entonces rey de Inglaterra trajo como consecuencia la amenaza de un ataque inglés a las costas ibéricas. La celeridad con la que se actuó en las prevenciones vino también en alguna medida fomentada por la urgencia del peligro, que ayudó a agilizar los trámites necesarios para preparar la defensa. Un primer resultado positivo de las peticiones del duque fue el envío de don Pedro Girón - consejero de Estado y Guerra - como gobernador de Cádiz. El duque encargó a su agente que se lo agradeciese a Olivares, en la confianza de que del mismo modo se haría con el resto de disposiciones que él estimaba necesarias. Para ello el agente debía mantener su presión, «no contentándoos hasta ver el remedio y la respuesta de todo lo que propongo, pues veis que la sazón es a propósito», en una línea de aprovechamiento de las situaciones de peligro que ya hemos visto. Tan conforme quedó el duque por entonces del resultado de las primeras gestiones de Vallejo que le encargó que trasmitiese su agradecimiento también al secretario Anaya, dándole el tratamiento de «buen amigo»145.

En mayo de 1625, Vallejo describió a Medina Sidonia una entrevista que había tenido con el conde-duque, quien, a la salida de una reunión del Consejo de Estado, al atardecer, en el momento en el que en el patio del Alcázar dejaba su silla de manos para introducirse en un coche, «a la vista de muchos», pidió al agente que se entrase con él y le acompañase sólo ${ }^{146}$. Allí habló de lo muy agradecido que estaba al duque por los muchos servicios que hacía a Su Majestad, a lo cual repuso el agente que eran muy merecidas las gracias y aún muchas mercedes, pese a que su señor nada ambicionaba más que la gratitud regia y que sus acciones tuviesen fama. Olivares se cuidó de halagar el crédito de Medina Sidonia remarcando que sin duda las acciones del duque eran de todos conocidas en Madrid y que él mismo estaba tranquilo de que estando don Manuel Alonso en su puesto nada grave podía suceder por aquella frontera. Sobre Cádiz solicitaba el valido al duque que cuando acudiese a la almadraba ese año entrase en la ciudad e hiciese una inspección a fondo y una relación del estado de las obras. Más aún, pedía al duque que supervisara las defensas, "pues aunque está allí don Fernando Girón asistiendo a la obra, Vuestra Excelencia es el dueño de todo». Además, Olivares aseguraba que iba a facilitar la llegada de cierta partida de dinero para dar cumplimiento a lo que fuera menester, quedando Cádiz obligada a Medina Sidonia también por esta merced que Olivares hacía a la ciudad gracias al duque. La respuesta al margen de don Manuel Alonso mostraba su confianza en la resistencia que podrían hacer al inglés en caso de que llegasen a tratar de tomar Cádiz si todo proseguía por aquellos cauces $^{147}$. El éxito de Cádiz mostró las buenas perspectivas que abría esta colaboración, aunque la interpretación de los hechos y del papel del duque en la defensa no estuvo exenta de polémica ${ }^{148}$.

${ }_{145}$ ADMS, leg. 3.001, d. 457, carta de 23 de febrero de 1625.

146 Según ElLiott, que sigue en esto a Marañón y a Simón Díaz, el coche de Olivares era su segundo despacho. En El conde-duque..., p. 291.

147 ADMS, leg. 3.001, d. 453, cartas de 22 y 30 de mayo de 1625.

148 Aunque la interpretación que aquí defendemos sobre la relación de Olivares con Medina Sidonia está matizada, sobre la polémica por escrito, ver SALAS AlmELA, Luis: «Combates después de 
Años después, a la llegada a Madrid de don Gaspar de Liébana —agosto de 1628 - como nuevo agente del duque, se abrió otro periodo de visitas a los familiares más cercanos y contactos más estrechos en la Corte, sin embargo no tan extensivo como el de Vallejo en 1623. El duque quedó satisfecho del buen trato que se dispensaba a su nuevo representante, en espera de que aún mejorase si mantenía sus visitas. Como recordara el duque a Liébana, «ya fuisteis advertido lo que cada uno puede hacer para la buena dirección de lo que está a vuestro cargo». Sin embargo, la visita al conde-duque tenía un tratamiento especial, quedando reservada para el último lugar. De todas las reuniones del agente el duque pedía informes inmediatos, aunque desgraciadamente tampoco hayamos podido localizar tales misivas ${ }^{149}$. En todo caso, parece que la sintonía de aquellos años entre Olivares y el duque don Manuel Alonso se mantuvo estable toda la década de los años de 1620. El reflejo más evidente era el asiduo recurso del duque a la mediación personal del valido - y no, en general, de sus secretarios o hechuras - con un considerable grado de satisfacción por ambas partes. Baste recordar la intervención del conde-duque en la composición del pleito de la alcabalas, en cuya negociación la representación del duque la llevaron el valido y el Patriarca de las Indias. También en materia de mercedes y prevenciones de guerra Olivares se mostraba atento a satisfacer a su primo. Así, mientras en el verano de 1629 el duque insistía en una nueva amenaza sobre los presidios africanos bajo su mando, aprobaba a Liébana que hubiese acudido a tratar con el valido «solicitando los decretos y recaudos que tenía que despachar de las mercedes que Su Majestad me hizo y que esto sea en la forma que yo lo he pedido y Su Excelencia me lo ha concedido». Al protonotario también remitía carta con el mismo fin ${ }^{150}$.

Desde otro punto de vista, la labor de solicitador extra-institucional de los negocios de su señor que cumplía el agente del duque, fuese o no favorable la acogida a sus propuestas, precisaba de mucha sutileza en este nivel. Convenía que el agente cuidase su imagen ante los contactos cortesanos de su señor, evitando parecer pedigüeño. Para ello, cuando en el otoño de 1630 Medina Sidonia remitió unos pájaros exóticos que le habían pedido el conde-duque y el

la batalla: Nobleza, propaganda política y servicio (Cádiz, 1625)» en Actas del III Congreso de Historia de Andalucía, Córdoba, 2002, pp. 293-308. Sobre la representación visual en el Salón de Reinos ver BROWN, Jonatan y ELLIOTT, Jonh H.: Un palacio para el rey, Madrid, 1998. Señalemos que, aparte de que los personajes del conocido cuadro de Zurbarán sobre la defensa de Cádiz no han sido aún identificados, el único cuadro que falta de la serie de batallas es el segundo de los que se ocupaban del asalto de 1625, lo cual deja abierta la posibilidad de que la labor del duque hubiese quedado reflejada en él. Ver también el reciente catálogo de la exposición sobre el palacio del Buen Retiro: ÚBEDA de los CoBos, Andrés: El palacio del Rey Planeta. Felipe IV y el Buen Retiro, Madrid, 2005, pp. 135-137.

149 El agente había quedado asentado con su sueldo como tal el 18 de agosto, según le informó don Lorenzo Dávila desde Sanlúcar. ADMS, leg. 3.063, cartas de 28 de agosto y 24 de septiembre de 1628.

150 ADMS, leg. 3.063, carta de 18 de agosto de 1629. 
marqués de Leganés, don Manuel Alonso ordenó a su agente que asistiese a la entrega acompañando al Patriarca de las Indias «porque os vean que asistís cuando les sirvo y que no sólo les veis para embargarles con negocios, si bien todos los míos se reducen al servicio de Su Majestad y defensa de mi justicia sin conocer pretensiones» ${ }^{151}$.

Al fin, con la instalación en Madrid en 1630 del heredero del ducado de Medina Sidonia, el conde de Niebla, enviado por su padre a tomar contacto con la Corte real, la labor del agente perdió importancia relativa. Esta instalación del conde respondía a la propia experiencia del duque, que enseñaba que una vez hubiese heredado sería muy complicado que tuviese ocasión de abandonar Andalucía. De la presencia en Madrid del heredero, además, el duque esperaba que pudiese hacer instancias que favoreciesen los pleitos y aspiraciones de la Casa, como vimos ${ }^{152}$. Sin embargo, el experimento de la sal simboliza a la postre un cambio sustancial en el clima de cordialidad existente entre Medina Sidonia y el gobierno de Felipe IV y Olivares. Aunque la documentación propia de la agencia madrileña no aporta casi información cualitativa de los últimos años del duque don Manuel Alonso, sabemos que la creciente presión militar fue haciendo cada vez más difícil perpetuar el equilibrio de servicio y merced hasta entonces mantenido. Si a eso sumamos el desgaste notable que para las principales rentas de la Casa ducal estaba suponiendo el deterioro del comercio atlántico, podremos entender mejor las tensiones de aquellos últimos años. Al fin, el rompimiento de la guerra con Francia en 1635 supuso para los duques la culminación de una escalada bélica en lejanos escenarios que sólo repercutía negativamente en sus fuentes de riqueza. Excluido el comercio francés, el retraimiento general en la Baja Andalucía estaba garantizado, ya que las débiles escuadras hanseáticas o polacas difícilmente podrían suplantar a bátavos y franceses en volumen de negocio.

\section{CONCLUSIÓN: EL CRÉDITO DE UN SEÑOR AUSENTE}

Cuando el príncipe de Esquilache alabó a Medina Sidonia su decisión de permanecer en la grandeza de su Casa y corte $(v . s)$, distaba mucho de estar haciendo un desprecio de Corte y alabanza de aldea al uso de la tradición de Antonio de Guevara. O al menos no era ese el concepto que los duques de Medina Sidonia tenían de su propio retiro sanluqueño. En su encendido Elogio al retrato de su señor de hacia 1626, Pedro de Espinosa describió el momento en el que el duque don Manuel Alonso recibió la herencia de la corona ducal refi-

151 ADMS, leg. 3.063, carta de 21 de octubre de 1628.

152 Hay que lamentar la falta de documentación generada por esta presencia del heredero del ducado en Madrid, lo cual reduce a conjeturas cualquier hipótesis sobre su actividad y contactos en la Corte. 
riendo que la noticia de la muerte de su padre le llegó estando en Huelva, «en el mayor gusto de su vida, regando las lechugas como Diocleciano, que nada falta al que nada desea». La nueva hizo exclamar al ya VIII duque «hoy acabo de vivir: no mi padre, que vive a la gloria y a la fama. Púsoseme el sol; cayeron para mí las sombras mayores» ${ }^{153}$. En efecto, para un Medina Sidonia la agitada corte, el centro de sus obligaciones y representación política era Sanlúcar, no Madrid. La ética del desengaño nobiliario que implica la retirada a los estados - y el consecuente cultivo de la correspondencia como deshago y vía de expresión ${ }^{154}$ _ cuadra mal en el caso de los Medina Sidonia, porque su retiro dista mucho de la recreación literaria del mundo de la aldea. Incluso no parece exagerado relacionar una parte del prestigio que poseía el género epistolar entre los nobles castellanos con esta ausencia de la Corte de los grandes nobles andaluces, los más conspicuos representantes del estamento. Las cartas, como recurso para trabar contacto con el monarca y sus principales ministros, así como con los demás grandes señores castellanos, responden en este caso más a una necesidad por ellos creada que a una cuestión estilística o de habitus nobiliario. La ausencia de la Corte era para estos grandes un reflejo directo de su propio poder, el cual les permitía permanecer al margen de la obligación de solicitar merced en propia persona por los pasillos del alcázar para aumento de sus casas y estados.

Ir a por atún y a ver al duque es un dicho castellano que, si bien ya en desuso, aún conserva la memoria de la importancia que tenía la corte ducal de Sanlúcar de Barrameda como foco de atracción de fidelidades políticas ${ }^{155}$. Aunque su significado no es unívoco ${ }^{156}$, el duque aludido es el de Medina Sidonia, el atún el de sus famosas almadrabas y la ida el viaje inverso al que hacía un agente de Medina Sidonia a Madrid. En este trabajo hemos estudiado la presencia de los Pérez de Guzmán en la Corte del rey a través de un sistema de representación delegada, su agencia. Por medio de ella los Medina Sidonia solicitaban al rey, hacían escuchar su voz y litigaban. Pero sería erróneo ignorar que aquella representación también canalizaba las fidelidades que la corte de Sanlúcar, como otras grandes cortes nobiliarias, era capaz de concitar, incluso dentro de la propia Corte real. Según el modelo de redes clientelares, el agente se asemejaría a un broker de su distante patrón, sólo que su mediación sería inversa, es decir,

153 Rodríguez Marín: Pedro Espinosa...p. 268.

154 BOUZA, Fernando: «Escribir en la Corte. La cultura de la nobleza cortesana y las formas de comunicación en el Siglo de Oro», en Acta Salmanticensis. Estudios Históricos y Geográficos, (Salamanca) 119 (2003) [Homenaje al profesor Ángel Rodríguez Sánchez], pp. 77-99; y Palabra e imagen en la Corte. Una historia cultural del Siglo de Oro, Madrid, 2003.

155 Agradezco a don Luis Salas Sánchez-Manzanera que me llamara la atención sobre el significado de este refrán.

156 Según una de las interpretaciones posibles, el dicho se aplicaría en tono burlesco a aquellos a los que se quiere tachar de presuntuosos por lo mucho que dicen poder - o privar- con quienes tienen poder; otra más directa sería la de señalar a quien aprovecha una ocasión para obtener un segundo y mayor beneficio. 
ejercida desde el territorio hacia la Corte regia. Esta diferencia desvirtúa notablemente el esquema de patrón-broker-cliente, hasta el punto de hacerlo poco útil a los efectos de entender las dinámicas políticas de una gran Casa señorial, cuya aspiración era el fortalecimiento de su poder en su área de influencia, construido con los mismos medios con los que el monarca buscaba imponerse - aquellos que la historiografía tradicional llamó estatales.

A partir de este punto, en la medida en la que los gestores del patronazgo regio - los patrons de Kettering, los validos o los secretarios de despacholuchaban por acaparar el favor regio, debemos replantear la naturaleza de las relaciones de las facciones con los poderes no cortesanos ${ }^{157}$. La imagen historiográfica de la Corte del rey Católico, ese espacio de formación de clientelas y escenario de luchas de grupos de poder, sigue sin dar cabida adecuada a otros poderes no cortesanos al margen de las oligarquías municipales. De hecho, esta es la gran diferencia de una agencia de representación nobiliaria frente a las concejiles o regnícolas: su cometido esencial no es tanto la mediación entre "Corte y aldea» como la defensa de un interés muy específico, como es el señorial ${ }^{158}$. De ahí se deriva que para entender la función de la representación nobiliaria haga falta dar cabida al esfuerzo de los grandes señores territoriales por aparecer como fuente alternativa de patronazgo. Por otro lado, junto a la centralidad otorgada por la historiografía a la articulación de las relaciones Corona-municipios - que, desde luego, ha sido el motor de importantes innovaciones-, la historiografía sobre las clientelas regias o facciones ha centrado en exceso su atención en aquellos individuos o grupos que figuran en los listados de consejeros o servidores de palacio ${ }^{159}$. Seguramente buena parte de este olvido se deba a las propias fuentes utilizadas, casi en exclusiva de origen real, completadas a veces con avisos de Corte e historias de los reinados. Las consecuencias historiográficas son tanto más llamativas cuanto que el objeto de estudio de estos mismos trabajos sobre la Corte a veces exige prestar atención precisamente a la composición de los grupos de presión. Por ejemplo, habiendo destacado los especialistas del periodo que la consolidación de la privanza de Lerma en los meses posteriores a la muerte de Felipe II se logró en gran parte mediante una política matrimonial de enlaces con las principales Casas castellanas, las alianzas no cortesanas parecen no contar más que como adornos genealógicos. Así sucede con Medina Sidonia, a cuya vinculación matrimonial con

157 Kettering, Sharon: Patrons, Brokers and Clients in Seventeenth Century France, Oxford, 1986. De la misma autora «Patronage in Early Modern France», en French Historical Studies, 17 (1992), pp. 839-862.

${ }^{158}$ Cfr. Ruíz IbÁÑEZ y MUÑOz RodRíGUEZ, «Sirviendo a la Corte...»

159 Carencia que no es exclusiva de la historiografía española, sino en general de los estudios sobre el valimiento. Véase por ejemplo, para el caso inglés, el estudio de Linda LEVY PECK, en el cual se echa en falta un marco que desbordase lo cortesano. En «El monopolio del favor: estructuras del poder en la corte inglesa de comienzos del siglo XVII», en ELLIOTT, Jonh H. y BROCKLISS, Laurence: El mundo de los validos..., pp. 81-104. 
la hija del valido apenas se ha prestado más atención que mencionar el enla$\mathrm{ce}^{160}$. Algo semejante sucede en el caso del valimiento de Olivares, cuyo ascenso ha sido presentado como consecuencia del poder de una llamada facción Guzmán-Haro-Zúñiga de la que, sin embargo, la cabeza del primer elemento del tridente familiar - los Medina Sidonia — quedaba no ya ignorada, sino abiertamente situada en la oposición ${ }^{161}$. Desde luego no era ésta la imagen que de sí daban ambos guzmanes a lo largo de la década de 1620 — y aún bien entrada la siguiente-, en la cual algunos de los planes del nuevo valido armonizaban perfectamente con los intereses de los duques —así la política naval o de fomento del comercio simbolizada por la creación de la Junta de Comercio ${ }^{162}$.

Visto desde la perspectiva del poder que aspiraba a ser dominante en la Corte, ¿en qué medida podía interesar atraer a su órbita el poder de un señor ausente? En primer lugar, precisamente en la condición de los grandes señores territoriales como polos de poder capaces de competir en alguna medida con el regio en el ofrecimiento de recompensas. En nuestro caso, aquel «rey de la Andalucía» sin título que era el duque de Medina Sidonia era capaz de promocionar carreras en su propia administración y de enriquecer a quien le sirviese, favoreciendo también ascensos — con oficios y dignidades no sólo militares- en la administración regia o, por el contrario, de entorpecerlas. De este modo, más allá del «supremo honrador» que era el rey, como árbitro del privilegio ${ }^{163}$, existían intereses diversos y argumentos que podían contrarrestar las expectativas de ascenso al servicio real en caso de tener que optar entre uno y otro. En el ámbito andaluz, esta capacidad de Medina Sidonia de atraer fidelidades le hacía poco menos que imprescindible para el éxito de cualquier política regia en aquella región. En todo caso, esta manifestación flexible del poder señorial, perceptible incluso en la Corte real, se resumía en el polisémico concepto del crédito ${ }^{164}$.

160 García García, Bernardo: La Pax Hispánica. Política exterior del duque de Lerma, Lovaina, 1996; Feros: El duque de Lerma...; Allen, Paul C.: Felipe III y la Pax Hispánica, 1598-1621, Madrid, 2001 [Yale, 2000]; pese a que la cuestión es más tangencial al objeto preciso de su estudio, aporta más información MARTínez HeRnáNDEZ, Santiago: El marqués de Velada y la Corte en los reinados de Felipe II y Felipe III. Nobleza cortesana y cultura política en la España del Siglo de Oro, Valladolid, 2004.

${ }^{161}$ Entre los que excluyen al elemento Medina Sidonia de la facción figura STRADLING Robert A., Felipe IV y el gobierno de España, 1621-1665, Madrid, 1989 [Cambridge, 1988]; entre quienes defienden la existencia de un rencor secular ELLIOTT: El conde-duque..., en concreto ver el capítulo I, «La herencia de los Guzmán», pp. 27-67.

162 ElLIOTT: El conde-duque..., pp. 159 y siguientes.

163 Álvarez-Ossorio, Antonio: «El arte de medrar en la corte...», p. 49; MARTínez Millán, J., «Introducción: la investigación sobre la elites del poder», en MARTíneZ MiLLÁN, J. (ed.), Instituciones y elites de poder en la Monarquía Hispana durante el siglo XVI, Madrid, 1992, 11-24.

${ }_{164}$ Para Sebastián de Covarrubias la primera acepción de este término era «la credulidad que damos a lo que se nos dice», asociando a continuación los términos de opinión y reputación. Tesoro de la lengua castellana o española, edición de Martín de RIQUeR, Barcelona, 1998 [Madrid, 1611], p. 368. 
Componente esencial del crédito de un poderoso señor era la constancia de su ejercicio, aquella que genera el hábito de la obediencia ${ }^{165}$. De ahí deriva en buena medida la búsqueda de los Medina Sidonia del reconocimiento de su actividad militar en la costa andaluza ${ }^{166}$. Cuando, en 1633, el agente del duque refirió a su señor la noticia que se tenía en el Consejo de Guerra de sus servicios, Medina Sidonia respondió que

«parte de premio es, a lo menos para mí, que me pago de que se conozca lo que sirvo. Lo que me referís que ahí hablaban la verdad es, que no hay en este mundo más que la salud y la hacienda»167.

Crédito del duque, por tanto, como garante de la defensa de la costa andaluza. Crédito también como capacidad de mover recursos económicos y de gratificar favores por diversas vías, según el estatus social de quien se tratase. Pero crédito así mismo entendido como estabilidad en el aprecio regio, cuyas consecuencias se plasmaban en la propicia intervención que, en no pocas ocasiones, obtenía en su favor el duque proveniente del entorno más íntimo del monarca o incluso del soberano, tanto en sus pleitos como en el desarrollo de la estructura militar en Andalucía o en la iniciativa de intervención en África.

Ahora bien, teniendo en cuenta que en sí misma la atracción de fidelidades era un valor considerable para el fortalecimiento del poder de un gran señor, cabe preguntarse si toda la aspiración política de un grande en la Corte se limitaba a la obtención de mercedes regias compensatorias por los servicios prestados o si, más bien, había una búsqueda de intervención — en nuestro caso en la distancia- en la política regia, cuando menos en el nivel local. Hay que preguntarse además si eran los grupos cortesanos los que obligaban a los grandes señores ausentes a tomar posición o si eran tales facciones las que pugnaban por atraerse el favor de aquéllos como parte de su estrategia de ascenso, consolidación y ejercicio del poder. Una explicación posible de la notable capacidad de la Casa de Medina Sidonia para sobrevivir políticamente a las mudanzas habidas en la Corte reside en que su autoridad y poder la hacían imprescindible para la facción vencedora. Frente a las inestables carreras de Corte ${ }^{168}$ —incluida la del valido-, la historia política de los Medina Sidonia hasta la conjura de 1641 —elemento este realmente extravagante por sus consecuencias a largo plazo en la historia de la nobleza castellana - se nos presenta como un llamativo ejemplo de estabilidad en un alto grado de favor. Esto no significa, desde luego, que los Pérez de Guzmán no debi-

165 PoPITZ, Heinrich: Fenomenologia del Potere. Autorita, dominio, violenza, tecnica, Bolinia, 2001 [1986].

166 Por ejemplo, en 1583 a Medina Sidonia se le ofreció la gobernación de Milán, siendo rechazada para reforzar la posición de preeminencia militar adquirida tras la campaña de Portugal. Ver Salas Almela: Colaboración y conflicto..., p. 48.

167 ADMS, leg. 3.063, 20 de noviembre de 1633.

168 MARTínez HeRnándeZ: El marqués..., pp. 99-101. 
eran cuidar con sumo tacto al monarca y a sus elegidos. De hecho, la vinculación familiar era un buen aliado en el acercamiento a la Corte que debía ser reforzado por todo un despliegue de demostraciones de afinidad y cercanía ${ }^{169}$. La línea divisoria entre el cultivo del favor del valido y el del monarca se hace muy tenue, desde esta perspectiva. Me inclino más bien a pensar que, en el caso de la alta nobleza con fuerte implantación territorial, el vínculo, más que con los privados, se establecía de forma mucho más clara a través de éstos con el propio monarca. El aspecto instrumental del valimiento cobra así su pleno sentido: entenderse con el favorito era una forma de garantizar la proximidad de la propia voz al oído del monarca, el cual tampoco podía permitirse no escucharla. Se puede considerar como fracaso de un valimiento el no haber sabido lograr el apoyo de varios de estos grandes señores a la política que en nombre del rey iba a defender.

Sin embargo, bajo aquella necesidad mutua se oculta el esencial conflicto o tensión de dos fuerzas expansivas llamadas a enfrentarse en una serie de roces casi constantes $^{170}$. La acción de la Corona limaba aspectos del poder señorial o mermaba sus fuentes de ingresos, mientras que la oposición señorial ayudaba a dejar en papel mojado no pocas disposiciones reales. Además, muchos de los procedimientos, rara vez originales, por medio de los cuales la Corona procuraba extender su margen de acción eran utilizados por los poderes señoriales para fortalecer el suyo. Al fin y al cabo, una parte sustancial de eso que se ha llamado estado moderno fue una técnica gubernativa mucho antes - en el tiempo y como concepto- que un proyecto político. Aquel conflicto entre los Medina Sidonia y sus reyes, sordo pero evidente, se desarrollaba tanto en Andalucía como en la Corte. Ésta, la Corte real, era, si se me permite la imagen, un tablero en el que el propio monarca tenía necesidad de emplearse a fondo para hacerse obedecer frente a las múltiples resistencias generadas en sus propias instituciones, eso sí, participando como jugador de ventaja, contexto en el que cobra pleno sentido la figura del valido $^{171}$. Si los juegos políticos en la Corte real eran en algún modo cajas de resonancia de las tensiones territoriales, hay que suponer que los equilibrios de poder cortesano necesitaban contar, para imponerse en palacio, con el apoyo de aquellos polos de poder más o menos distantes, sobre todo si el espacio físico que ocupaban era de tanta importancia estratégica para la Monarquía como la Baja Andalucía. En resumen, desbordado el marco tradicional de estudio de la política de Corte, generalmente limitada al espacio intramuros del alcázar, podremos acercarnos a una más cabal comprensión de la política moderna.

169 Desde el acuerdo de 1569 para casar al VII duque con la hija del príncipe de Évoli, el criterio dominante en la selección de esposas por los Medina Sidonia fue la vinculación con relevantes personajes de la Corte hasta la década de 1670, con la única excepción del IX duque.

${ }^{170}$ Cfr. Passola i Tejedor, A., «Poder local y poder real: un pacto tácito», en Bravo Lozano (ed.) Espacios de poder..., 45-71.

${ }^{171} \mathrm{La}$ imagen del rey necesitado de imponerse en su propia Corte ha sido defendida por Irving A.A. THOMPSON a la hora de abordar el fenómeno del valimiento. En «El contexto institucional de la aparición del ministro-favorito» en ELLIOTT y BROCKLISS (dirs.): El mundo de los validos..., pp. 25-41. 